\title{
THE ROLE OF ANIMAL-SOURCE FOODS IN HEALTHY, SUSTAINABLE, AND EOUITABLE FOOD SYSTEMS
}

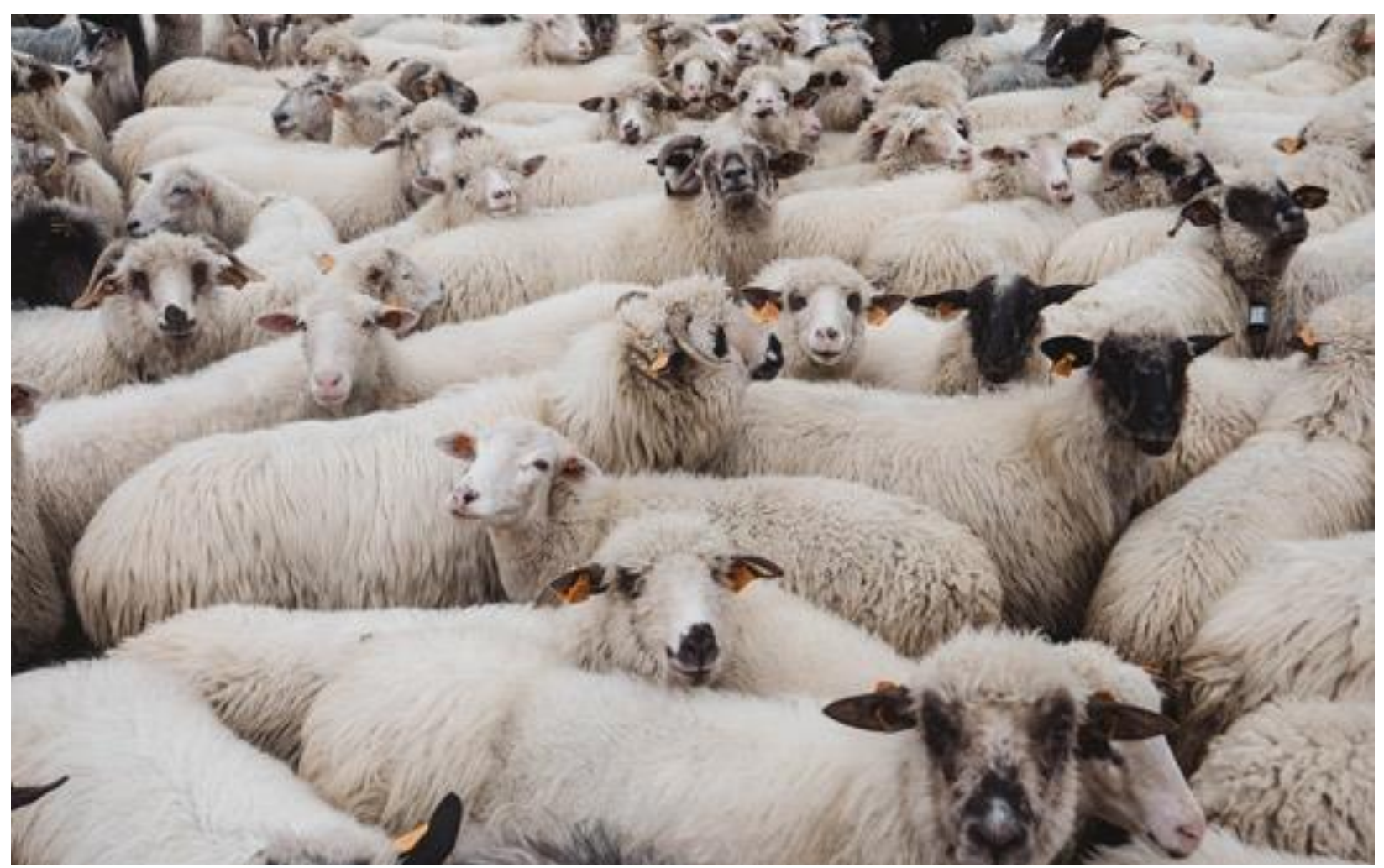

GAIN Discussion Paper $n^{\circ} 5$

May, 2020

Stella Nordhagen, Ty Beal, and Lawrence Haddad

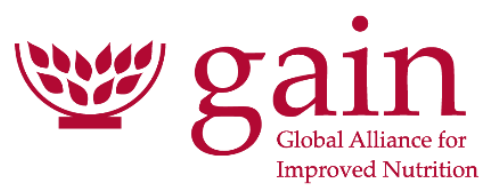




\section{ABOUT GAIN}

The Global Alliance for Improved Nutrition (GAIN) is a Swiss-based foundation launched the UN in 2002 to tackle the human suffering caused by malnutrition. Working with governments, businesses and civil society, we aim to transform food systems so that they deliver more nutritious food for all people, especially the most vulnerable.

\section{Recommended citation}

Nordhagen S, Beal T, and Haddad L. The role of animal-source foods in healthy, sustainable, and equitable food systems. Global Alliance for Improved Nutrition (GAIN). Discussion Paper Series \#5. Geneva, Switzerland, 2020. DOI: https://doi.org/10.36072/dp.5

\section{(C) The Global Alliance for Improved Nutrition (GAIN)}

This work is available under the Creative Commons Attribution-Non-Commercial-Share Alike 4.0 IGO licence (CC BY-NC-SA 4.0 IGO; https://creativecommons.org/licenses/by-nc-sa/4.0/). Under the terms of this licence, you may copy, redistribute, and adapt the work for non-commercial purposes, provided the work is appropriately cited, as indicated below. In any use of this work, there should be no suggestion that GAIN endorses any specific organisation, products or services. The use of the GAIN logo is not permitted. If you adapt the work, then you must license your work under the same or equivalent Creative Commons license. The contributions of third parties do not necessarily represent the view or opinion of GAIN.

\section{Acknowledgements}

We thank Lynnette Neufeld, Saul Morris, and Kathryn Dewey for their review and comments on earlier drafts of this paper. All photographs included in this document have been taken with consent for use in publications.

\section{GAIN DISCUSSION PAPER SERIES}

The GAIN Discussion Paper series is designed to spark discussion and debate and to inform action on topics of relevance to improving the consumption of nutritious, safe foods for all, especially the most vulnerable.

The Global Alliance for Improved Nutrition (GAIN)

Rue de Varembé 7

1201 Geneva

Switzerland

T: +41227491850

E: info@gainhealth.org 


\section{SUMMARY}

Among the major issues facing the global population are persistent malnutrition (including both undernutrition and overweight/obesity), climate change, and environmental degradation. At the crossroads of these issues, animal-source foods (ASF; meat, poultry, fish, dairy, and eggs) have attracted considerable attention for both their role in diets and their environmental impacts-and their production also plays an important role in livelihoods, particularly in low- and middle-income countries (LMICs). As these issues are intertwined, they must be considered jointly and with sufficient recognition of the nuance involved. This paper aims to add to this debate through a review and discussion of evidence on ASF spanning several dimensions: nutrition, health, environment, livelihoods, and equity. We discuss the nutritional properties of different types of ASF and their potential for preventing undernutrition, then consider potential health risks associated with the consumption of certain ASF. We next turn to production, summarising how various ASF production systems affect the environment, indicating that there is considerable variability depending on context and animal. We note some gaps in the environmental impacts literature, then consider the role of animal production in livelihoods as well as equity concerns. We then briefly discuss diets with potentially lower environmental impacts. The paper concludes by bringing together these different dimensions to summarise potential ways forward for decision making around ASF-whilst making clear how nuanced and context-specific such decisions must be.

\section{KEY MESSAGES}

- ASF consumption tends to be higher in high-income countries, whereas undernutrition in highest in LMICs-and overweight/obesity is an increasingly global phenomenon.

- Minimally processed ASF are good sources of many nutrients, often in higher concentrations or more bio-available forms than in plant-source foods; their consumption can be particularly beneficial to vulnerable groups.

- Excess consumption of certain ASF can lead to health problems, but overall diet quality is the most important factor in determining health risk.

- Environmental impacts of ASF production include greenhouse gas emissions, land use change, pollution, and biodiversity changes; they vary by type of ASF, production system, context, and type of impact but are generally greatest for ruminant meat. There are some options for reducing impacts.

- ASF production is integral to livelihoods in many LMICs, and some livestock (particularly ruminants) play important roles in farming systems and societies.

- When considering ASF, the associated and interlinked health, nutrition, environmental, and livelihood outcomes should be assessed jointly — with an eye to equity and a grounding in local context, as well as an understanding of the diversity among different types of ASF. 


\section{BACKGROUND AND OBJECTIVE}

Despite large advances in recent decades, malnutrition remains widespread. Stunting (short height for age, a sign of chronic undernourishment and/or infection) affects about $21 \%$ of children under five (1), and a large share of the global population is likely deficient in essential micronutrients (2). Such deficiencies have serious and lifelong consequences, being associated with cognitive impairment, poor child development, decreased work productivity, lower disease resistance, and higher mortality (3); negative effects can persist across generations (4).

Undernutrition increasingly coexists alongside overweight and obesity. Overweight and obesity alone affect over 2 billion adults worldwide, and an estimated 48 countries (predominately lower-income countries) suffer from a double burden of high prevalence of both undernutrition and overweight (5). Overweight/obesity and poor diets are associated with increased risk of a number of non-communicable diseases (NCDs), such as diabetesthe prevalence of which has nearly doubled in recent decades $(6,7)$. Micronutrient malnutrition and stunting, both partially caused by inadequate diet quality (8), limit the ability of developing children to reach their growth and developmental potential (9-11). Poor diets have negative health consequences throughout life and have been estimated as the largest risk factor contributing to the global burden of disease, responsible for about $22 \%$ of adult deaths (12). Malnutrition thus reduces quality and length of life for millions worldwide, preventing them from reaching their full potential. While it cuts across all countries and varies within them, low-income populations and those in low- and middleincome countries (LMICs) are most affected.

At the same time, humanity and the planet on which it depends face an ongoing and growing existential threat: climate change and environmental degradation. At levels of warming of $2^{\circ} \mathrm{C}$ above pre-industrial levels—which is considered optimistic given current levels of emissions (13) - there will likely be considerable changes in precipitation patterns, rising sea levels, greater coastal flooding, and increased frequency and severity of extreme events (such as drought, heat waves, cyclones, and wildfires) (14). These are expected to lead to, among other things, increased loss of biodiversity, lowered agricultural productivity, changes in the nutrient content of crops, and increased hunger and mortality $(14,15)$. Progress addressing the issue has been paralyzingly slow: countries have collectively failed to halt growth in greenhouse gas (GHG) emissions, and deep cuts are urgently required to maintain hope of remaining below key temperature-increase thresholds (16). In addition to climate change, the earth's water systems are overburdened and polluted, deforestation and habitat destruction are ongoing, and biodiversity is lost daily (17-19).

Food systems - the processes, actors, and infrastructure involved in providing food, from production to consumption - sit at the intersection of these issues as providers of essential nutrients for human diets, users of natural resources, and emitters of GHG and other pollutants. Within food systems, animal-source foods (ASF; meat, poultry, fish, dairy, and eggs) have attracted attention for both their importance in diets and their environmental impacts. ASF demand has been increasing and is projected to increase slightly in high- 
income countries (HICs) and considerably in LMICs over the next three decades (20-22). This growth could have substantial negative environmental impacts if carried out following existing production practices $(23,24)$. However, it could also play a key role in reducing undernutrition and supporting livelihoods, particularly in LMICs.

It is essential to consider these issues jointly, and in context, aiming to understand how each concern manifests within a given geography and how best to balance amongst them. In so doing, one must consider not only environmental and health factors but also the role of animal production in livelihoods and the equity concerns integral to the just mitigation of environmental change. The optimal balance is likely to be very different across development contexts.

This paper aims to add to this debate. We discuss the important role of different types of ASF in preventing undernutrition, as well as the potential health risks associated with their consumption. We then consider how production of various ASF affects the environment, including considerable nuance across production system and animal type. We briefly consider the role of animal production in livelihoods as well as equity concerns. Finally, we conclude with suggestions for how to move forward on making policy decisions related to ASF that balance human nutrition and wellbeing with environmental health, equity, and livelihoods. While we recognise the importance of also considering animal welfare issues, that is beyond the scope of the present paper. The next section sets the stage for the discussion by describing the current context of global nutrition and diets.

\section{NUTRITIONAL CONTEXT}

Malnutrition, including undernutrition, overweight, and diet-related NCDs, is a global phenomenon with no population untouched. Among children under five, nearly a quarter (21\%) are stunted, 7\% are wasted, 6\% are overweight, and over half are deficient in micronutrients (e.g., iron, vitamin A, zinc) vital for healthy development (1). Anaemia affects one third of women of reproductive age (25). As shown in Fig. 1a for stunting, the largest burden of undernutrition occurs in LMICs. Overweight, in contrast, is particularly common in high-income regions but increasing in every region in the world (26). As shown in Fig. 1b, globally, $18 \%$ of those 5 to 19 years are overweight (a considerable increase since 2000, when it was $10 \%)$ and $39 \%$ of adults 18 years or older are overweight $(25,27)$. Diet-related NCDs (i.e., heart disease, type 2 diabetes, and some cancers) are also widespread (28), and diabetes is increasing globally, with particular rapidity in LMICs (6). For example, the disability and disease burden associated with diabetes in sub-Saharan Africa (SSA) more than doubled between 1990 and 2017 (29). 


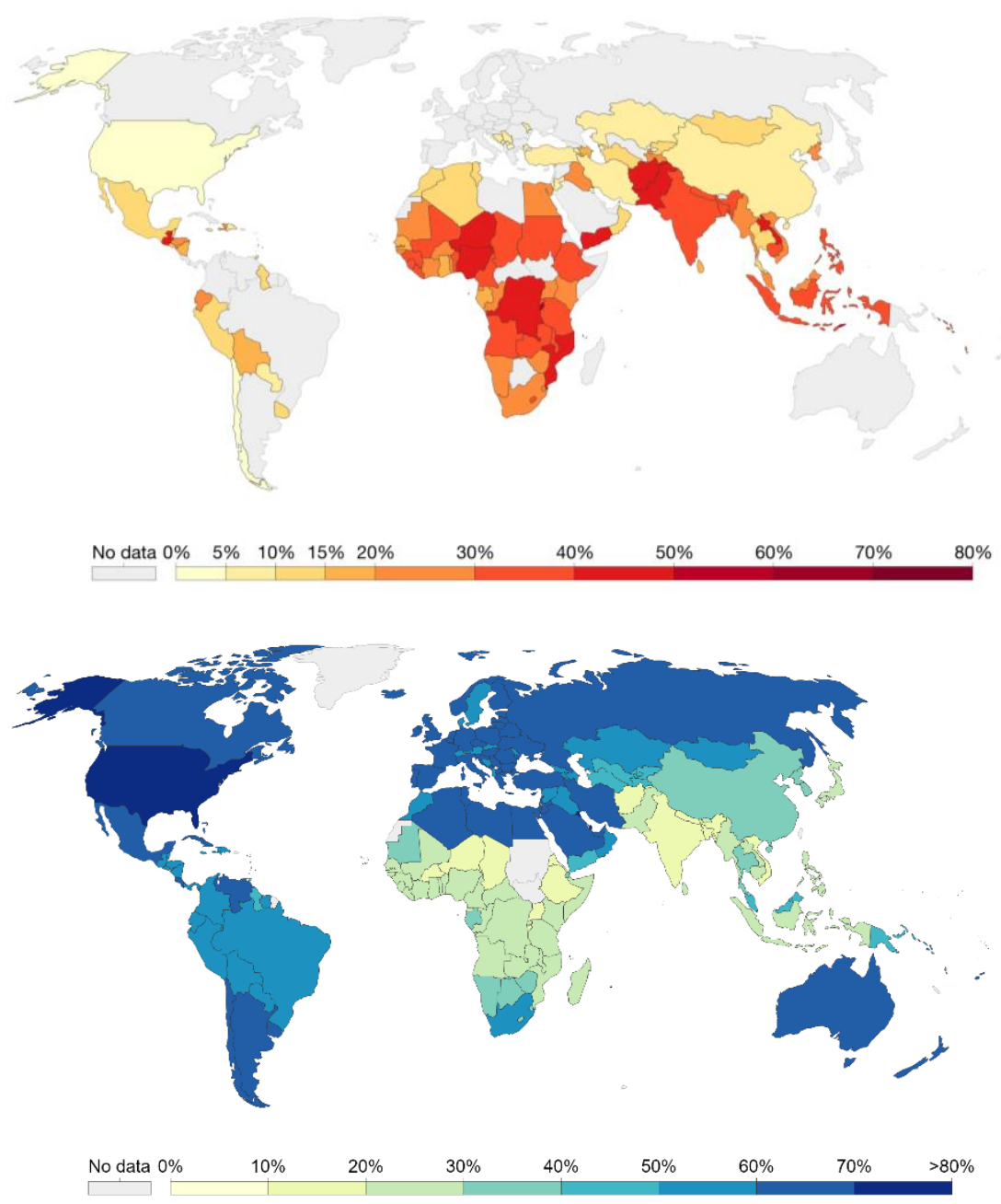

Figure 1. (a - top) Share of children under 5 y who are stunted, 2016; data source: UNICEF/WHO. (b - bottom) Share of adults $18 \mathrm{y}$ and older who are overweight or obese $(B M I>=25), 2016$; data source: UNICEF/WHO. Both graphs reproduced from 'Our World in Data'; permission not required.

Malnutrition is driven by a wide range of factors, with inadequate diets being one of the most important. At a global scale, consumption of several key food groups deviates from recommended levels: according to the 2017 Global Burden of Disease Study collaborators, fruits, vegetables, whole grains, nuts, and seeds (all examples of minimally processed plantsource foods (PSF)) are consumed at below-optimal levels (based on health risk minimisation) in all major world regions, whereas legumes are under-consumed in over half of world regions (12). In terms of ASF (Figure 2) and using the same data source, milk and fish are under-consumed in most regions but particularly in LMICs in Asia and SSA (12). Consumption of meat, eggs, and poultry varies widely across countries but tends to be lowest in LMICs in Asia and SSA and highest in high-income North America (12).

Meanwhile, consumption of unhealthy highly processed foods (including both PSF and ASF), and of the sodium, trans-fats, and sugars they often contain, is high in HICs (and some middle-income countries) $(12,30,31)$ and growing quickly in LMICs (32-34). These food consumption patterns (jointly) drive nutritional outcomes. The next section argues that ASF play an important role in this, particularly for preventing undernutrition. 


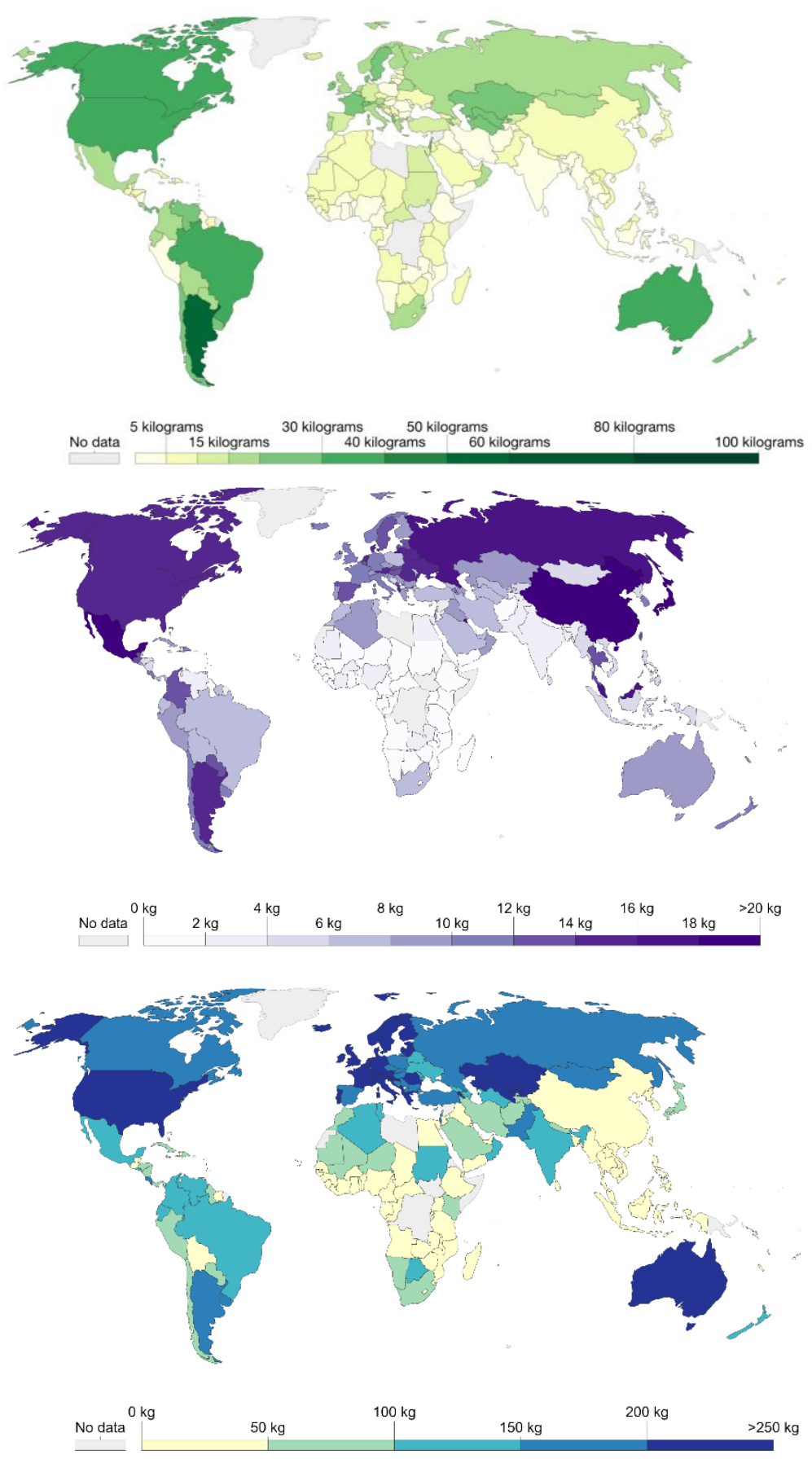

Figure 2. (a - top) per capita beef and buffalo meat consumption; (b - middle) per capita egg consumption; and (c - bottom) per capita milk consumption; all data are in kilograms per person per year and do not account for food waste at the consumer level; beef/buffalo meat data are from 2013, others are from 2017. Data source: United Nations Food and Agriculture Organisation (FAO). Graphs reproduced from 'Our World in Data'; permission not required.

\section{NUTRITIONAL CONTRIBUTION OF ASF}

ASF - including meat, freshwater and sea animals, eggs, and dairy - have unique beneficial properties that distinguish them from PSF. ASF typically contain higher concentrations and more bioavailable forms of nutrients commonly lacking in diets in LMICs, including iron, vitamin $A$, zinc, calcium, vitamin $B_{12}$, and high-quality protein (35-38). Moreover, consumption of ASF can also enhance absorption of nutrients from PSF (39). There are also bioactive compounds unique to ASF, especially dairy products, that can have beneficial 
health effects. ASF are the only natural dietary sources of vitamins $B_{12}$ and D. Vitamin $B_{12}$ deficiency has immediate and long-term consequences including anaemia, developmental regression, and depression during adulthood $(40,41)$. Vitamin D deficiency causes rickets in children, contributes to osteoporosis and bone fractures, and has been associated with increased risk of infectious disease and NCDs (42).

While PSF contain vitamin A, iron, zinc, and calcium, these micronutrients are less bioavailable than in ASF due to their chemical form, the surrounding food matrix, and antinutrients like phytate and oxalate in PSF (43). Zinc deficiency is associated with poor health, increased risk of diarrhoea, and impaired cognitive and motor development $(44,45)$. Calcium deficiency increases risk of rickets, but its broader health implications are poorly understood (9). ASF are the only dietary sources of retinol (preformed vitamin A), which on average is 12 times more bioavailable than plant sources of vitamin A (carotenoids) (1). Moreover, some individuals are genetically poor converters of carotenoids and likely to be deficient without consuming preformed vitamin A (46). Vitamin A deficiency has severe consequences, including night blindness, increased susceptibility to infections, and death (47). Meat is the only source of heme iron, a form of iron that is much more bioavailable than the non-heme iron found in PSF (48). The proportion of iron that is heme iron varies from $65-72 \%$ in beef and lamb, 39\% in pork, and $26 \%$ in chicken and fish $(49,50)$. Iron deficiency is a primary cause of anaemia in many contexts and can result in cognitive impairment, decreased work productivity, and death; even without accompanying anaemia, iron deficiency is an important cause of cognitive impairment (51).

Most ASF contain 'complete' or high-quality proteins, which include all nine essential amino acids in adequate quantities necessary in the human diet and important for child growth $(37,38)$. Diets without ASF must typically include a wider variety of foods and combine varying food types to provide all amino acids in adequate quantities (52). While it is possible to do this, affordability, knowledge, and other constraints may make it difficult, particularly in low-resource settings. Finally, ASF, particularly fatty fish, contain essential long-chain omega-3 fats (i.e., DHA and EPA), which have numerous health benefits, including improved child development, healthier aging, and reduced inflammation (53). The only plant sources of DHA and EPA are sea vegetables, which are not widely available and accessible in sufficient quantities. While certain land PSF, like flaxseeds, contain a shorter chain omega-3 fat (ALA), this does not have the same health benefits, and less than $10 \%$ is converted to DHA or EPA (53).

ASF can be particularly important for reducing undernutrition among vulnerable groups in resource-poor settings. Infants, young children, and adolescents are undergoing periods of physiological change and accelerated growth; pregnant and lactating women have higher nutrient requirements due to foetal growth and milk production (38). As such, these groups are particularly vulnerable to nutrient deficiencies and associated negative health outcomes—such as anaemia, poor brain development, and poor growth—if key micronutrients are insufficiently consumed $(35,38)$. Obtaining adequate high-quality protein and micronutrients from PSF can be particularly challenging for young children, who have small stomachs, as fairly large volumes are typically required. Since ASF tend to be dense in 
many nutrients, smaller amounts can be eaten to meet requirements. For example, about $50 \mathrm{~g}$ of chicken liver provides the recommended daily intake of iron, vitamin $\mathrm{A}$, zinc, vitamin $B_{12}$, and folate from complementary foods for breastfeeding children ages 6-23 months $(54,55)$.

ASF are thus ideal complementary foods (i.e., foods to be provided in addition to breastmilk beginning at six months of age) (56). Observational studies have found significant associations between ASF consumption and reduced odds of child stunting (e.g., (57-59)), and some randomised controlled trials (RCTs) have demonstrated that ASF consumption can improve micronutrient status, growth, and/or cognitive performance (6062).' Dietary studies have shown that even when optimising consumption of locally available plant-source foods, it is very difficult to meet nutrient requirements for several micronutrients (64). The evidence for the translation of additional consumption of ASF into improved functional outcomes, however, is limited. Recent systematic reviews have not reached clear conclusions about the effects of ASF on child growth or development (65-67); more research is thus needed.

While ASF can help vulnerable populations obtain adequate nutrients, food is more than its nutrients. Bioactive compounds-extra-nutritional chemicals found in both plants and animals in small quantities_can also have beneficial health effects. Certain bioactive compounds are unique to ASF, including conjugated linoleic acid (CLA), certain bioactive peptides, and insulin-like growth factor 1 (IGF-1). CLA has been shown to prevent or reduce risk of cancer, inflammation, cardiovascular disease, metabolic disease, and fat deposition as well as increase muscle mass and improve immune response (68). Bioactive peptides from ASF can influence the cardiovascular, digestive, endocrine, immune, and nervous systems to lower cholesterol and blood pressure, improve mineral absorption and immune responses, and reduce blood clots, genotoxic activity, and obesity (69). Finally, ASF have been shown to increase IGF-1, which may improve growth in children (70) and reduce cancer and death in the elderly (71). ${ }^{2}$ Of note, throughout this section we have considered minimally processed ASF and PSF: processing can result in large changes in nutritional value-discussed in more detail in the next section.

\section{POTENTIAL HEALTH AND NUTRITIONAL DOWNSIDES}

While ASF clearly have valuable nutritional properties, high consumption of certain ASF can be harmful, particularly when processed or prepared in unhealthy ways, such as with considerable amounts of sodium and preservatives and/or cooked at high temperatures, well-done, smoked, or deep fried. High consumption of ASF can also be problematic for certain age groups, like those in middle age, when increased IGF-1 may increase risk of cancers and death (71). Moreover, individual components in certain ASF, including saturated fat, cholesterol, trimethylamine $\mathrm{N}$-oxide, heme iron, antibiotics, and hormones, as

\footnotetext{
${ }^{1}$ Another trial was unable to replicate this result (63), although this may have been because of the existing high consumption of ASF and high burden of infection in the study population.

${ }^{2}$ IGF-1's potential negative effects are discussed in the next section.
} 
well as additives like sodium and preservatives, have been implicated as contributing to disease. In this section, we discuss these factors in detail.

Saturated fats exist in a variety of PSF and ASF, and evidence on their health impacts is mixed. A 2015 Cochrane review on the topic (72) included 15 RCTs assessing the impact of replacing saturated fats with carbohydrates, unsaturated fats, and/or protein on mortality and cardiovascular morbidity. It found a slight reduction in a composite endpoint of cardiovascular events but no difference on cardiovascular or all-cause mortality. However, a re-analysis of the included studies using a different method found no significant reduction in risk of combined cardiovascular events, a high risk of publication bias in the original review, and significant heterogeneity of included studies (73). ${ }^{3}$ A 2010 meta-analysis of RCTs found that replacing saturated fats with polyunsaturated fats resulted in reduced cardiovascular events (74). However, this study included trials with substantial differences in diets between treatment and control groups. ${ }^{4}$ A 2016 systematic review (75) that included 84 RCTs assessing the effects of lowering saturated fat intake on serum lipid and lipoprotein concentrations provided evidence that replacing saturated fats with unsaturated fats improves serum lipid and lipoprotein concentrations. However, it is unclear whether these changes significantly lower cardiovascular morbidity or mortality, and the type of saturated fat and food source are important $(76,77)$, as well as the quality of the overall diet (78). Several other systematic reviews and meta-analyses of RCTs and observational studies (79-83), a large observational study of over 100,000 individuals $(84,85)$, and some leading experts (76) have not found evidence that saturated fat significantly increases risk of NCDs or death, on average.

Cholesterol is only found in ASF. Similar to saturated fat, dietary cholesterol has historically been implicated in disease, particularly cardiovascular disease, by raising plasma cholesterol concentrations. However, dietary cholesterol from eggs has recently been shown to not significantly elevate plasma cholesterol concentrations, aside from in a minority of 'hyper responders' (86). More importantly, numerous umbrella reviews, systematic reviews, and meta-analyses of observational studies suggest dietary cholesterol does not increase risk of NCDs, including cardiovascular disease, in the general population (87-91) and that foods high in cholesterol may slightly reduce risk of stroke $(88,89,91)$ and type 2 diabetes (91).

Trimethylamine-N-oxide (TMAO) is abundant in fish and can be generated in the gut from precursors, including choline (present in eggs) and carnitine (present in beef). Many studies have found a correlation between high levels of TMAO and cardiovascular disease, but whether or not foods that produce increased levels of TMAO increase risk of cardiovascular disease is unclear $(92,93)$. Evidence is mixed on whether consumption of eggs and meat

\footnotetext{
${ }^{3}$ For example, the Cochrane review included the 1966 Oslo Diet-Heart study, in which the treatment group, in addition to replacing saturated fat with soybean oil, received a large dose ( $5 \mathrm{~g} /$ day $)$ of EPA/DHS from sardines canned in cod liver oil and was advised to restrict sugar and refined carbohydrates. It also included the 2006 Women's Health Initiative study, in which the treatment group, in addition to lowering total and saturated fat, increased intake of fruits and vegetables.

${ }^{4}$ This included the 1996 Oslo Diet-Heart study as well as the Finnish Mental Hospital study, which was not an RCT_all participants from one hospital were assigned to treatment, all from a second hospital to control; additionally, participants in the control group were disproportionally exposed to a cardiotoxic drug, thioridazine.
} 
leads to meaningful increases in TMAO (92-96). However, fish increases TMAO levels about 50 times more than either eggs or beef $(93,94)$, and the health benefits of fish, particularly its cardioprotective attributes, are well established $(53,97)$. For this reason, it is unlikely that moderate consumption of ASF containing TMAO or its precursors significantly increases risk of cardiovascular or other NCDs, but further research is required.

Heme iron, as discussed in the prior section, helps prevent iron deficiency. However, studies have found high intakes to be associated with increased risk of NCDs and death (98-101). While dietary reference intakes do not specify upper limits of heme iron, populations that consume large amounts of red meat would likely benefit from reducing intake and/or increasing consumption of PSF high in antioxidants and iron inhibitors, including fruits, vegetables, whole grains, legumes, nuts, and seeds.

Harmful components in ASF can be introduced from particular methods of production and processing. Many forms of ASF production use mass administration of antibiotics to animals to proactively prevent and control disease and increase growth and production efficiency (102). ASF production is responsible for over half of global antibiotic consumption, and antibiotic use is increasing rapidly, especially in LMICs $(102,103)$. Antibiotic use in ASF production is directly linked with antibiotic resistance, which can increase morbidity and death from infectious diseases (104). Endocrine disruptors make their way into ASF through the food and water that animals consume, the environment in which they live, and hormones used to promote growth (105). These endocrine disruptors interfere with humans' natural hormone functions, which can negatively impact reproduction, development, and behaviour (105).

Processing, including preserving, salting, drying, smoking, and cooking, can improve or reduce the nutrition of ASF (and PSF). Preservatives, including sodium, nitrites, and nitrates, are often added to processed meats. High sodium intake, particularly in conjunction with low potassium intake, can increase the risk of cardiovascular disease, stroke, and mortality, especially in hypertensive, older, and black populations; low levels of sodium can also increase risk of cardiovascular disease and death (77,106-108). Nitrates and nitrites in processed meats have been associated with cancer, cardiovascular disease, and diabetes (109-111), although the strength of the evidence has been challenged $(112,113)$. When meat is cooked at high temperatures, well-done, or smoked, it can produce heterocyclic amines and polycyclic aromatic hydrocarbons, which may be carcinogenic and/or mutagenetic in humans (114-116).

In summary, while individual components within certain ASF likely contribute to specific diseases, the quality of the evidence for these associations is relatively weak - in part because the type of ASF and the level of processing has not always been adequately taken into consideration. High intakes of processed red meat are associated with increased risk for chronic diseases, such as heart disease, stroke, diabetes, and cancer $(23,117-119)$. The evidence of health risk associated with intake of unprocessed or minimally processed red meat is mixed, but intake beyond a small to moderate amount likely contributes to risk for chronic diseases $(23,113,117-119)$. There is little evidence of health risk associated with 
unprocessed or minimally processed ASF other than red meat, such as poultry, fish, eggs, or dairy $(88,120-124)$. ASF consumption is currently not considered a primary contributor to the diet-driven disease burden in LMICs, at least in part because of low levels of consumption, particularly of highly processed varieties (12). Increased consumption of certain ASF, such as fatty fish that is rich in protein, micronutrients, and omega-3 fats, may reduce undernutrition and risk of chronic diseases simultaneously $(125,126)$.

Finally, the quality of the overall diet is most important. For example, low intake of beneficial minimally processed PSF like fruits and vegetables or high intake of harmful PSF like sugar-sweetened beverages, fast foods, and highly processed snack foods containing trans-fat, refined flours, sugars, and oils can be highly detrimental, regardless of the amount of ASF consumed $(12,77,127-131)$.

\section{ASF AND THE ENVIRONMENT}

\section{ENVIRONMENTAL IMPACTS OF ASF PRODUCTION 5}

About $83 \%$ of the animal-source protein consumed worldwide comes from livestock (i.e., land-based animals), with the remainder from fish and seafood (via aquaculture and capture fisheries; 2015 estimate, (132)). ASF can be produced using a range of practices, including those that are regenerative and sustainable $(133,134)$. However, the majority of current practices of ASF production globally are largely unsustainable and contributing to climate change and environmental damage (135-138). Livestock production and aquaculture use land, biomass, and water resources and can result in excess emission of $\mathrm{GHG}$ such as $\mathrm{CO}_{2}$ (carbon dioxide), $\mathrm{CH}_{4}$ (methane), and $\mathrm{N}_{2} \mathrm{O}$ (nitrous oxide) as well as other soil and water pollutants $(138,139)$.

Livestock use approximately $30-40 \%$ of global land (about $80 \%$ of agricultural land $(136,140))$, with a portion of this being in mixed crop-livestock systems $(135,140-142)$. However, much of this land use is not in competition with food crops, as grazing can occur on lands unsuited to crop production $(141,143)$. Only about $43 \%$ of the land used for feed production could be re-allocated to direct production of human food (i.e., as cropland) (141). However, land use conversion for grazing land or feed crops is a major concern in some areas; for example, it is estimated to have caused most Amazon deforestation (144). Grazing land is projected to increase slightly by 2050, with estimates ranging from $-5-25 \%$ above 2009 levels, depending on assumptions about production levels and practices (145). This is in addition to cropland expansion for feed crops. Feed production uses about half of agricultural land (141), and the demand for feed is expected to grow by 6-17\% from 2010 to 2025 (141). Such land use change generally has negative implications for biodiversity, carbon sequestration, and other ecosystem services. Livestock can also negatively affect biodiversity through over-grazing, spreading disease, competition with wildlife, water pollution, and competition between feed crops and native plants (146), but the relationship

\footnotetext{
${ }^{5}$ Livestock also play roles in the transmission of disease, environmental enteric dysfunction, and the rise of antibiotic resistance, and animal welfare is an important concern in animal production. However, these issues are beyond the scope of this paper.
} 
between biodiversity and livestock is highly complex and context-specific (140). Indeed, every ecosystem on earth includes plants and animals, many living in stable, symbiotic relationships. Capture fisheries and aquaculture (through the use of wild-caught fish as feed) can also have negative impacts on aquatic biodiversity (147), and aquaculture has resulted in considerable loss of global mangroves, an important ecosystem for carbon sequestration (147).

Livestock also use about $8-10 \%$ of global fresh water $(136,140)$ (about a third of the total fresh water used for agriculture (148)), with the vast majority (98\%) of this being used for feed production $(23,136,149)$. Indeed, feed production from croplands consumes $37 \%$ of the total water for crop production (150). Unlike GHG, the location of land and water use matters: competition between livestock, crops, and humans for water and land can sometimes entail trade-offs, particularly in arid water-stressed areas $(146,151)$, which are projected to increase substantially in coming years (152).

Livestock contribute approximately $15 \%$ of global anthropogenic GHG emissions (23), with estimates varying depending on source, methods, and assumptions (135-137,153-156) and some researchers disputing that the figure is this high (157). Aquaculture (including feed) and fishing vessels contribute about $2 \%$ and $1 \%$ of global GHG emissions, respectively (147). Feed production is the main process driving emissions for livestock, accounting for $45 \%$ of global livestock emissions (154). Livestock in LMICs contribute $50-65 \%$ of total livestock emissions (150). Exact breakdowns by type are also disputed and geographically varied, but the largest contributor is likely $\mathrm{CH}_{4}$ (primarily from ruminants' enteric fermentation ${ }^{6}$ ), followed by $\mathrm{N}_{2} \mathrm{O}$ (from manure and slurry), and $\mathrm{CO}_{2}$ (from land use and land use change, with smaller amounts contributed by transport and fuel use) $(135,136,140)$. Each of these GHG differs somewhat in its impact on global warming.?

Unsustainable agricultural production (including of livestock and feed crops as well as food crops) also plays a key role in disrupting the natural nitrogen and phosphorus cycles, with negative environmental consequences (24). When excess amounts of nitrogen and phosphorus are released into an ecosystem, they can lead to acidification and eutrophication, harming local plant and animal species. ${ }^{8}$ Among livestock, the risk of this is highest for pork and beef production (137). The leaching of livestock manure can also contaminate water sources with pathogens and toxins, including antibiotic residues $(140,160)$.

\footnotetext{
${ }^{6}$ Ruminants use microbial fermentation in the rumen, a digestive organ, to convert fibrous plants like hay into soluble nutrients; $\mathrm{CH}_{4}$ is produced as a by-product.

${ }^{7}$ While the bulk of $\mathrm{GHG}$ in the atmosphere is $\mathrm{CO}_{2}, \mathrm{CH}_{4}$ is a very potent $\mathrm{GHG}$, with a warming potential 28-36 times that of $\mathrm{CO}_{2} ; \mathrm{N}_{2} \mathrm{O}$ has a warming potential 265-298 times that of $\mathrm{CO}_{2}(158) . \mathrm{CH}_{4}$ and $\mathrm{N}_{2} \mathrm{O}$, however, dissipate relatively quickly in the atmosphere, making the rate of emissions more important than the cumulative level of emissions-in contrast to $\mathrm{CO}_{2}(23)$. This also means that reductions in these gases can have a very efficient impact on reducing GHG in the atmosphere. Emissions from multiple gases are often converted into a single number, the $\mathrm{CO}_{2}$ equivalent $\left(\mathrm{CO}_{2} \mathrm{eq}\right)$ for easy comparison, though it has been argued that such methods overestimate the effects of $\mathrm{CH}_{4}, \mathrm{~N}_{2} \mathrm{O}$, and other shorter-lived $\mathrm{GHG}$ (159).

${ }^{8}$ Acidification results from emission of various chemicals from fertiliser, manure, and fuel; excess acidification makes it difficult for plants to assimilate nutrients, decreasing growth. Eutrophication refers to the increase of nutrients (e.g., phosphate, nitrogen, oxides, ammonia) entering an ecosystem and can have substantial environmental impacts (e.g., algal blooms, aquatic dead zones) (138).
} 
At the same time, livestock also play an important role in supplying nutrients: it is estimated that manure accounts for $14 \%$ of nitrogen, $25 \%$ of phosphorus, and $20 \%$ of potassium in soils (161). Where fertiliser use is very low (e.g., SSA), livestock can be the only source of key soil nutrients $(162,163)$. However, efficiency of such nutrient cycling is generally lower in LMICs than in HICs (150). Cattle contribute about $60 \%$ of these nutrients, with pigs and chicken each contributing about 9-10\% (146). Livestock can also increase biodiversity if grazing is properly managed and play an essential role in ecosystems that lack native herbivores (164). Rangelands sequester considerable amounts of soil carbon and can help improve ecosystem water productivity $(140,146)$. Livestock can thus be an integral part of agricultural ecosystems.

\section{VARIATION IN IMPACTS BY TYPE OF PRODUCTION}

The way in which livestock are raised (see Box 1) has considerable implications for their impact on the environment. A large portion of livestock's environmental footprint stems from feed production, and feed needs differ by production system, animal, and agroecosystem. Intensive systems rely more heavily on grain or legume feed (edible to humans), whereas extensive systems use grass, crop residues, or scavenged plants (nonedible to humans). While grain/legume feed requires more inputs to produce, this can come with important productivity trade-offs. For example, ruminants in many LMICs are fed predominantly using grass and stover (grain crop residues), requiring little additional resource input; however, they are also less productive and emit more $\mathrm{CH}_{4}$ per animal, partly due to this poor-quality feed (165). In terms of animals, beef cattle tend to require more

\section{BOX 1: PRODUCTION SYSTEMS}

Globally, animals are raised under a diverse range of systems, which can be grouped into pastoral/agropastoral, mixed crop-livestock systems (extensive or intensive, in terms of their resource input), and industrialised systems $(166,167)$. Pastoral systems rely on grazing (consumption of rangeland/pastures), mixed systems incorporate crops as inputs for livestock and livestock residue as inputs for crops, and industrial systems produce little or none of their own feed (166). Industrial systems are predominant in HICs, produce about $40 \%$ of global production (76-79\% of total production of pork, chicken, and eggs), and are expected to grow in LMICs in the future $(21,22,165)$. Pastoral (grazing) systems supply only a small amount of global meat production $(146,165)$, but use about $23 \%$ and $30 \%$ of land in OECD and lowincome countries, respectively (168). Mixed systems provide about $70 \%$ of ruminant meat and almost $90 \%$ of milk, as well as half of global cereals $(140,150)$. Mixed systems are of particular importance for food security and livelihoods in LMICs, as it is estimated that over $60 \%$ of the rural population lives in such systems (146). Fish and seafood can be obtained either through wild capture (fisheries) or aquaculture, where fish and seafood are raised for consumption. About $47 \%$ of fish and seafood currently comes from aquaculture, and this is expected to rise (169). However, aquaculture is highly spatially concentrated, with $90 \%$ of production in Asia and less than $1 \%$ in SSA (132). 
feed per unit produced than dairy cattle or pigs, and poultry are the most efficient terrestrial feed converter $(140,165)$. Part of this difference is unmodifiable, as it is shaped by the comparatively low reproductive and growth rates of ruminants: large amounts of food go to maintenance of the animal, as opposed to its growth or reproduction (136).

Overall, about $32 \%$ of grain production is used as feed (141), with most of this (78\%) fed to intensively raised pigs and poultry in middle- and high-income countries $(141,165)$. However, ruminants in most systems (aside from industrial feedlots) eat mostly feed that is not edible to humans and does not compete with cropland (141). Only about $14 \%$ of animals' feed is digestible by humans (141), and feed production also uses large amounts of agro-industrial by-products that could otherwise be waste (170).

In terms of animals, beef cattle typically use larger areas of land than dairy cattle, followed by pigs and poultry (137). While sheep and goats can be raised on particularly marginal land unsuited for other types of agriculture, they are often responsible for considerable degradation of vegetation and soil $(136,140)$. Cropland use per unit output is similar across mixed ruminant and pork/poultry systems, but cropland use for intensively raised ruminants is considerably higher, due to low feed conversion rates (136).

GHG emissions vary considerably by type of ASF. In general, monogastrics (e.g., pigs, poultry) are more GHG-efficient than ruminants, and milk, white meat, and eggs are more GHG-efficient than ruminant meat $(140,150)$. The emissions intensity of ruminant milk is well below that of meat (12-140 versus $58-1,000+\mathrm{kg} \mathrm{CO} 2 \mathrm{eq} / \mathrm{kg}$ edible animal protein), though this difference shrinks with higher-quality ruminant diets; pork production is much lower, at about $24 \mathrm{~kg} \mathrm{CO}$ eq $/ \mathrm{kg}$ protein, and poultry meat and eggs are lower still, at $3.7 \mathrm{~kg}$ $\mathrm{CO}_{2} \mathrm{eq} / \mathrm{kg}$ protein (165). This is largely due to feed- and land-use efficiencies: beef production can use up to five times the amount of feed per unit of animal protein as dairy (165), leading to large impacts on land use. ${ }^{9}$ The emissions profile also differs: for monogastrics, feed production is the main contributor to emissions under current production methods, followed by manure; they contribute primarily $\mathrm{N}_{2} \mathrm{O}$ and $\mathrm{CO}_{2}$. For ruminants, enteric fermentation is the main source of $\mathrm{GHG}$, in the form of $\mathrm{CH}_{4}$; feed production methods and manure also contribute significant amounts of $\mathrm{N}_{2} \mathrm{O}$ (171). As a result of these differences, cattle account for $77 \%$ of non- $\mathrm{CO}_{2} \mathrm{GHG}$ emissions (165).

This difference across animals is also partly driven by the high level of industrialisation of the pig and poultry sectors compared to that of ruminants (165). There is considerable heterogeneity in GHG-emissions intensity across livestock systems and across countries, with $\mathrm{HICs}$ and those production systems that use higher-quality feed (e.g., industrial monogastric systems) generally having lower emissions intensities (165). GHGs in extensive systems mostly stem from land use and land use change, land degradation, and enteric fermentation; in intensive systems, manure is a main source, with $\mathrm{CO}_{2}$ emissions from energy and input use also playing a role (140). Water use also differs by production system/animal, with extensive systems requiring more water for livestock themselves and intensive systems requiring water for cooling and cleaning; on balance, intensive systems

\footnotetext{
${ }^{9}$ The results of such comparisons would change somewhat if based on other nutrients, such as iron or calcium.
} 
tend to be more consumptive than extensive systems (140). Both intensive and extensive systems contribute water pollutants, with this being more concentrated in intensive systems due to greater livestock density (140). Intensive systems also result in greater soil nutrient depletion, as nutrients in animal waste do not return to the animals' supporting land base (140). In terms of animals, beef farming uses about three times the water per unit of meat as chicken (23).

Taken together, beef production uses the most land and energy and emits the most GHG, followed by pork, poultry, eggs, and milk; these differences are largely driven by differing feed efficiencies, $\mathrm{CH}_{4}$ emissions, and reproductive rates (137). Beef production is also responsible for more ecosystem acidification and eutrophication. On balance, industrial poultry production is likely the most efficient major form of livestock production (excluding fish); traditional poultry production has a low environmental impact (140), but this may not compensate for its low productivity. Extensive systems are more likely to lead to land use change and degradation (but can also sequester GHG), whereas intensive systems tend to use more nutrients and water and result in higher levels of soil and water pollution $(136,140)$. Overall, shifting from traditional mixed and extensive systems to more intensive systems probably improves land-use efficiency and reduces methane emissions from ruminants but increases emissions from manure, water pollution, and energy consumption and may harm biodiversity (140); changes in animal welfare may also result. ${ }^{10}$

The environmental impacts of capture fisheries and aquaculture vary significantly across context, species, and production/harvesting practice (169). Overall, energy use per unit protein production of fish is comparable to that of chicken and less than other livestock systems (e.g., pork, beef) (172). Fish tend to have a feed conversion ratio much lower than that of livestock, as most do not need to divert energy to maintain body temperature (173). Fisheries' GHG emissions come primarily from $\mathrm{CO}_{2}$ from ships' diesel use, with higher emissions intensities for trawling fisheries (138), which also have detrimental impacts on biodiversity. For aquaculture, feed production is the main source of GHG emissions and resource use (171). Fish feeds include both ASF (e.g., poultry-derived products, fishmeal) and grains, meaning fish farms are responsible for negative impacts through the same processes as crop and livestock production. By species, aquaculture GHG emissions are lower for molluscs and higher in production of finfish (e.g., salmon) and crustaceans, which relies on not only intensive feed but also aeration and water pumping to provide oxygen and disperse waste (147). Carnivorous fish (e.g., salmon, cod) tend to have higher emissions intensities due to their need for marine-based feed (171). Aquaculture also uses small amounts of land and water and can emit $\mathrm{CH}_{4}$, pollute water, or result in habitat destruction $(147,172)$. While capture fisheries have lower environmental impacts than aquaculture on many fronts, they put pressure on wild fish stocks_over $30 \%$ of which worldwide are already overfished—and associated ecosystems $(147,174)$.

\footnotetext{
${ }^{10} \mathrm{~A}$ recent meta-analysis found that compared to conventional systems, organic systems use less energy but more land and have a higher potential for eutrophication, with no difference for GHG emissions or acidification potential (138).
} 


\section{GAPS IN EXISTING KNOWLEDGE}

Whereas the amount of information available on the environmental impacts of livestock has grown massively over the past 15 years, with over 170 environmental impact assessments of livestock published (175), there remain gaps in information about production efficiencies, water use by source, environmental footprint, biodiversity impact, effects of processing, and economic and ecological opportunity costs in specific sites (136), particularly in the varied agroecosystems of LMICs. Reviews have shown that the vast majority of environmental lifecycle analyses for food products come from HICs, with only $0.4 \%$ from Africa (138); for foods as a whole, only $4 \%$ and $1 \%$ of 1,718 environmental impact estimates come from South America and Africa, respectively (176). Studies often focus on single dimensions of impact (e.g., GHG emissions), making it difficult to comprehensively assess a particular livestock system's environmental impact $(136,137)$ —and to balance that against its nutrition benefits. Studies that compare across foods also rarely include fish/seafood, a promising food group from a nutritional perspective (177), for which information on environmental impacts is incomplete (169).

\section{OPPORTUNITIES FOR REDUCING ASF'S ENVIRONMENTAL IMPACT}

Numerous options exist for reducing the environmental footprint of livestock production, though differing approaches will be needed across heterogenous production and consumption systems, in alignment with local ecosystems, policies, and livelihoods.

One of the most promising ways to reduce GHG emissions from livestock, particularly in LMICs, is through increased productivity (178), allowing smaller numbers of animals to be raised. As shown in Fig. 3, livestock productivity in LMICs is well below that in HICs; it has also barely grown in recent decades (179). With some variation by agro-ecosystem, there is a well-defined inverse relationship between efficiency of production and GHG emissions intensity: low-productivity animals consume resources at a higher rate per unit yield than high-productivity animals $(140,180)$. Indeed, SSA is the region with the greatest livestock emissions intensity, largely driven by low productivity arising from poor-quality and scarce feed and low-potential animals (165). In HICs, improved practices (as well as temperate conditions making for higher-quality feed) enable considerably lower emissions intensity. For example, per-unit emissions from bovine meat (in $\mathrm{kg} \mathrm{CO}_{2} \mathrm{eq} / \mathrm{kg}$ milk) in SSA are about two orders of magnitude larger than those in most HICs (165) — with large differences also seen in milk yield. Increasing productivity could thus allow for a reduction in GHG emissions without reducing production quantity $(146,181)$, though such improvements have limits (178). 


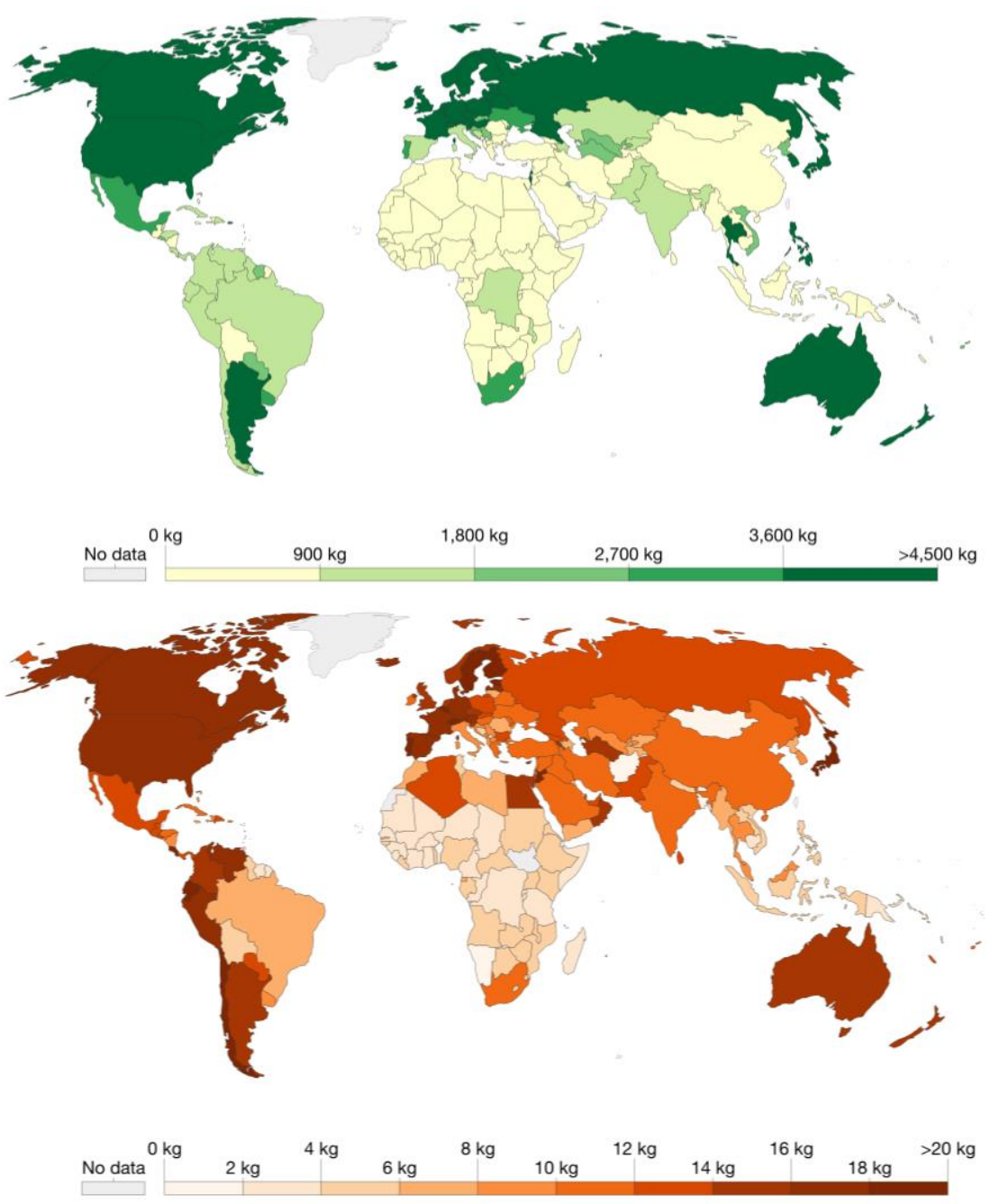

Figure 3. (a - top) Average yield of milk per milk-bearing animal and (b-bottom) eggs per bird; all data are in kilograms per animal per year, based on 2014 UN FAO data. Graphs reproduced from 'Our World in Data'; permission not required.

Productivity increases could come from improved breeds $(21,153,182)$, improved veterinary care and disease prevention (136), better animal husbandry practices $(153,170)$, or improved pasture management (e.g., rotation, improved pasture species) $(146,182)$. Higherquality feed is a particularly promising approach, as many LMIC livestock are undernourished (21). Feed is a key determinant of resource use, and feed-use efficiencies in LMICs are well below those in HICs $(136,153,165,181)$. Diet quality is also a determinant of ruminants' $\mathrm{CH}_{4}$ output and influences $\mathrm{N}_{2} \mathrm{O}$ emissions from manure (183). Improvements in animal diets could thus increase productivity—and perhaps ASF affordability (179)—while lowering emissions intensities (184). Shifts in production system (e.g., from grazing to intensive mixed) could achieve higher efficiency but would need to be carefully managed in terms of waste production, antibiotic use, animal welfare, and zoonotic disease $(21,150,153,165)$. There could also be some risk of increased productivity driving more negative impacts on other facets of resource use and environmental impact, aside from GHG emissions.

Beyond increasing productivity, different techniques for rangeland management can significantly reduce water use in such systems (185); techniques also exist for better 
managing water productivity in mixed systems (149). Deforestation could be reduced through intensification, improved productivity, and regulatory changes to avoid conversion of land for animal use; improved grazing management or silvopastoral systems (i.e., integrating trees, forage, and grazing) could increase biodiversity and soil quality and reduce water loss (140). In feed-based systems, reductions in the environmental footprint of feed production (e.g., through more efficient use of water and nutrients) could reduce that of the associated livestock, as well (140).

GHG emissions, nutrient loss, and water pollution could also be reduced through improved manure management and closer locating of livestock production near crop production or in more integrated systems in $\mathrm{HICs}$ - which could also help reduce GHG emissions from crop production, if manure replaced some mineral fertilisers $(140,150,153,186)$. Anaerobic digestion of manure to produce biogas could reduce GHG emissions from both manure and energy use $(181,187)$. Reducing waste along food value chains (which currently represents about one third of global food production) could have a large impact on emissions reductions across the food system, including for ASF (171), and diversion of food waste to livestock could help reduce overall food system GHG emissions (188). ${ }^{11}$ Improving the use of non-flesh parts of livestock (e.g., as food, or in beauty/pharmaceutical products) could help reduce economy-wide environmental impacts (189).

Another option is to shift between types of ASF, to those which use resources more efficiently. Shifts from ruminants to monogastrics could help increase efficiency and reduce $\mathrm{CH}_{4}$ emissions-e.g., replacing expected growth in beef production with equivalent growth in poultry production could reduce environmental impacts by 5-13\% (24). However, it could also increase demand for feed grains (and thus $\mathrm{CO}_{2}$ production from land use changes and $\mathrm{N}_{2} \mathrm{O}$ from manure management (146)) and reduce availability of dietary iron and zinc, which would need to be compensated for (e.g., with fortification or biofortification).

In the case of capture fisheries, emissions reductions of $10-30 \%$ could be attained through changes to vessels and engines, fishing gear, and/or speed (147). Additional work to prevent overfishing could also help, as emissions from fishing of overfished stocks are higher due to the need to cover larger areas (172). In aquaculture, large variations in emissions intensity across systems suggest considerable opportunities for improving their environmental performance (173). GHG emissions intensities could be reduced by an estimated $21 \%$ per tonne through feed changes, improved technologies, applying best practices, and use of renewable energy (147); development of novel feed ingredients and integrated aquatic polycultures are also promising (190).

There are also opportunities for sequestration of GHG in soil through livestock systems, particularly for degraded rangelands in LMICs (191). However, the extent of these benefits has been disputed and shown to vary widely by location (192-194). Overall, comprehensive mitigation packages are estimated to be able to reduce livestock emissions intensity by 14-

\footnotetext{
${ }^{11}$ Food produced and not eaten is responsible for the emission of $3.3 \mathrm{Gtonnes}$ of $\mathrm{CO}_{2} \mathrm{eq}$ (the third-highest global emitter, after the US and China), uses $250 \mathrm{~km}^{3}$ of surface water (three times Lake Geneva), and occupies about 1.4 billion hectares (nearly $30 \%$ of the world's agricultural land) (171).
} 
$41 \%(154,181)$, with considerable variation across system, species, and region. Mitigation potential within the sector is estimated to be lower than in other agriculture sectors (153); for example, under optimistic assumptions, mitigation potential in tropical livestock systems amounts to about $7 \%$ of agricultural mitigation potential (182).

These options can be used to reduce the environmental footprint of ASF production in LMICs, but none are 'quick fixes' and would inevitably contend with barriers to implementation, such as poor access to information, extension, and credit as well as policy and institutional challenges; change would need to happen in tandem with adaptation to ongoing climate change $(195,196)$. Adoption rates for agricultural technologies can be around $1 \%$ a year (182). As such, realistic estimates for resource-use reduction through improved practices tend to be well below theoretically possible reductions (136). Gender and equity concerns also need to be kept in mind when weighing options: livestock intensification, for example, would likely place a large burden on LMIC women (who may not be compensated for this time), whereas livestock commercialisation could lessen their control over livestock and associated products (150).

In addition to existing technologies, there is considerable potential for innovation in livestock production systems - such as developing new low-input feeds, including from insects (21) or seaweed-and in the efficient use of livestock products-such as by ensuring full use of offal meats, which are often denser in vitamins and minerals than muscle meat but widely underused, particularly in HICs (197). Aquaculture, as a relatively new field that has potential to produce a highly nutritious product, is particularly promising as a focus for innovation (190). There is also the possibility of creating lab-grown meat (21). However, it is likely that some reduction in ASF demand in HICs will be needed: the Intergovernmental Panel on Climate Change estimates the potential to reduce GHG emissions from livestock through consumption changes to be much greater than that of technical changes on the supply side $(139,153)$. Options for such consumption changes are discussed below.

\section{ASF PRODUCTION AND LIVELIHOODS}

Animal production is a source of not only food but also income. Livestock production directly supports an estimated 1 billion low-income smallholders in LMICs, including over $80 \%$ of low-income Africans (140), with particular importance in some of the world's poorest regions, such as the Sahel and Horn of Africa. Livestock value chains more broadly employ at least 1.3 billion people globally (146). An estimated 117 million people are engaged in fisheries and aquaculture, including postharvest jobs (198); whereas capture fisheries are fairly widespread across coastal nations, aquaculture as a livelihood has tended to be concentrated in a handful of countries (132). At a macro level, livestock (a comparatively high-value product) is responsible for $17-47 \%$ of the agricultural value of production in LMIC regions (150), and growth in livestock production has been shown to drive GDP growth (199) and have high potential for poverty reduction $(200,201)$. At the household level, livestock contribute income to $68 \%$ of LMIC households, are responsible for about one third of income from mixed cropping systems, and in some settings make the greatest 
percentage contribution to income for the poorest households (140). This income is essential for food security and nutrition in these households.

Livestock, particularly small ruminants and poultry, can be particularly important for women, as they represent an asset that is easier to acquire than land or other physical or financial assets $(202,203)$; women also tend to be highly active in the processing and sale of livestock products (150). Livestock, particularly sheep and goats, also can be raised on marginal lands unsuited for crops (140). Such lands are expected to increase under climate change, making livestock an important alternative to crop production in highly climate-exposed regions (143). Capture fisheries can similarly offer the main income-earning option in coastal and island nations ill-suited to agriculture.

While detailed breakdowns of livelihoods supported by type of livestock and type of system are unavailable, the majority of lower-income households in LMICS are engaged in extensive production within mixed farming systems $(140,167,204)$. Poultry are by far the most commonly kept livestock by number (205); small rural poultry flocks, in aggregate, account for $60-90 \%$ of the poultry population in many LMICs (206). Poultry rearing is normally seen as but one (often small) component of diverse livelihoods, but the income it contributes can be particularly important for poor households and women (206). Ruminants may make larger contributions to household incomes, and ruminant pastoralism is a particularly important livelihood to consider, as pastoralists are often among the poorest populations living in the most marginal areas, with few other livelihood options (204). As livestock value chains transition to rely more heavily on intensive production and formal markets, smallholders can be marginalised and the number of lower-income people supported by the associated livelihoods tends to be less (204). Such a transition is already underway in some LMIC regions, particularly for poultry and pigs $(165,167)$.

In addition to providing income, livestock (particularly ruminants) play multiple roles in LMICs. In mixed crop-livestock systems, livestock manure is used to enrich soil, and ruminants provide draught power for crop production, can improve soil structure, and control insects and weeds $(140,207)$. Livestock also provide non-food products, such as wool, and their waste can be used as cooking fuel or building materials $(140,170)$. Livestock function as an asset, which can be sold if needed; they thus can help to buffer risk, smooth household consumption, and increase resilience. Livestock can be sold to invest in small businesses or other livelihoods (208) and, in some cases, be used as collateral for loans (209). They_particularly larger livestock, such as cattle — may also play cultural roles (e.g., demonstrating social status, use in ceremonies or dowries) $(21,150)$. Shifts in livestock production would thus have profound implications for both livelihoods and cultures in LMICs. This underlines the importance of increasing productivity, which would benefit the food supply, environment, and wellbeing of households.

\section{ASF AND EQUITY}

Central to considering whether and how ASF production and consumption should change to benefit people and planet is the question of equity. Equity has been integrated into many global environmental policies, as in the concept of 'common but differentiated 
responsibility' of the 1992 United Nations Framework Convention on Climate Change. This placed the onus for combatting climate change on industrialised nations, given that they had produced the majority of prior GHG emissions and had the greatest capacity to adapt (210). Additional principles of fairness and equity are also relevant: that the parties with the most resources normally should contribute the most to a joint endeavour; that, if adequate supplies of a key resource exist for everyone to have enough needed for a decent life, it is unfair not to provide everyone with at least that adequate minimum; and that the most vulnerable deserve special consideration in policy formulation $(211,212)$.

The current situation of ASF consumption, environmental degradation, and malnutrition is deeply inequitable. GHG emissions per capita are highest in HICs (Fig. 4a), where ASF consumption is also highest-and levels of undernutrition are lowest (Figs. 1-2). Moreover, the impacts of climate change will likely be felt most acutely by low-income residents of LMICs (Fig. 4b) (212), exacerbating existing inequalities in wellbeing (213). The ability of LMICs to both mitigate and adapt to climate change is further limited by their levels of undernutrition — which is responsible for an estimated 11\% of GDP being lost every year (214). On the production side, hypothetical equal cross-country cuts in ASF production could be disproportionately felt by low-income rural residents of LMICs, whose livelihoods are more dependent on the sector (particularly for poultry and extensively raised ruminants). ${ }^{12}$ LMICs, on balance, thus bear less responsibility for overall GHG emissions (particularly when viewed historically $(216,217)$ ), they have lower capacity to adapt without harming large numbers of livelihoods, and their citizens could in many cases benefit from increasing their consumption of certain minimally processed ASF. Similar gradients exist across low- and high-income groups within countries (albeit with considerable variability) $(218,219)$.

\footnotetext{
${ }^{12}$ The livestock sector also supports livelihoods in $\mathrm{HICs}$, but this role is much smaller. While figures specific to livestock are unavailable, agriculture (including livestock) employs just 1-4\% of the population in most OECD countries (215).
} 

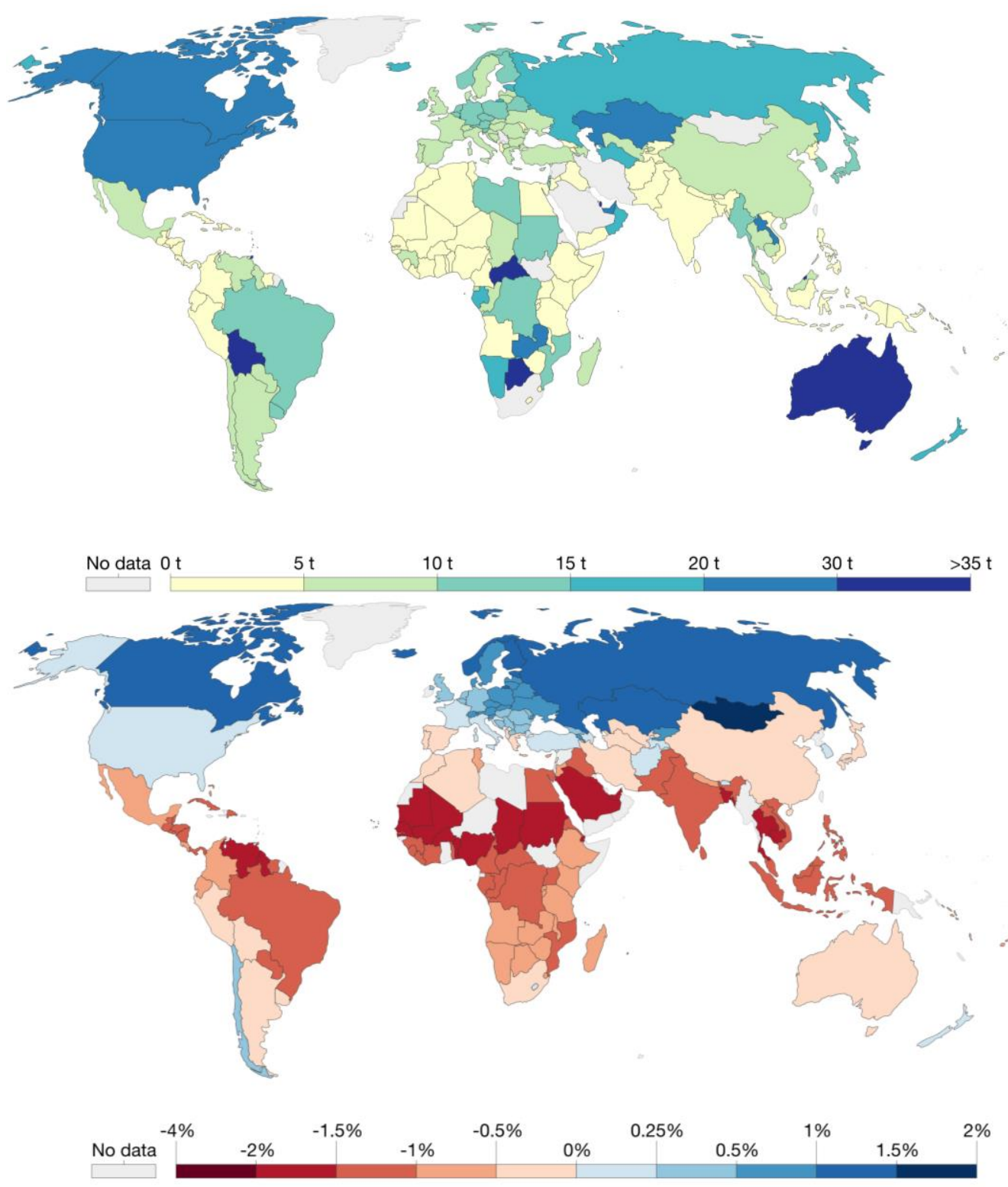

Figure 4 - (a - top) GHG emissions per capita, measured in + CO2eq per year; Data are from Emission Database for Global Atmosphere Research. (b-bottom) Projected economic impacts of climate change: projected change in GDP per capita growth under a $2 \circ \mathrm{C}$ increase in global mean surface temperature (compared to no additional warming). Data are from (220). Graphs reproduced from 'Our World in Data'; permission not required.

Viewing these facts through the lens of equity, it is clear that there can be no equitable onesize-fits-all approach to increasing the environmental sustainability of the food system vis-àvis ASF. Instead, it suggests that HICs need to drastically change their ASF production and consumption practices (and broader food systems) to give LMICs the opportunity to increase ASF production and consumption, where appropriate, for the benefit of nutrition and poverty alleviation. HICs and LMICs, meanwhile, must collaborate to boost productivity and lower resource intensity of ASF production in LMICs for the benefit of the environment. The relatively high levels of GHG emissions per capita from livestock in LMICs, despite low levels of production (221), imply considerable potential gains to be made through this route. Such an approach would be in line with definitions of sustainable diets and sustainable livelihoods, which recognise the importance of equitably balancing 
environmental impacts against the needs of present and future human generations $(222,223)$.

For those environmental effects that are locally specific, such as water use, the picture is more complicated: improvements in resource-use efficiency for the most nutritious ASF are more urgent, and equity dictates the importance of carefully balancing the needs of different local resource users (e.g., farmers, pastoralists) as well as those dependent on the food they produce (e.g., urban dwellers).

\section{THE ROLE OF ASF IN DIETS: CONSIDERING ENVIRONMENT AND NUTRITION}

Compared to ASF, PSF generally have significantly lower GHG emissions and land use (per unit mass and/or per calorie), particularly for field-grown vegetables and fruit $(138,176,224)$. For ruminant meat, the difference is large, sometimes over a factor of $100(138,224)$. Animal products also tend to have larger per-unit water footprints than crop products, with some difference by setting and type of water considered $(148,150,225,226)$. Eutrophication (i.e., excess nutrients entering an ecosystem) and acidification potentials are also considerably lower for most PSF than for ASF, though variations across systems are large (226). Of note, most such comparisons are based on energy, protein, or mass, which do not account for ASF's generally superior-quality protein, higher nutrient density and bioavailability, and higher energy density when compared to PSF. Given the general gradient in environmental impacts, however, a reduction in ASF consumption tends to be part of suggestions for alternative dietary patterns with lower environmental impacts.

One of the most ambitious of these, the 2019 EAT-Lancet Commission, suggested a 'healthy reference diet' that could keep the food system within boundaries for six earthsystems processes (climate change, nitrogen and phosphorus cycling, freshwater use, biodiversity loss, and land-systems change) (139). This diet included ASF as about $14 \%$ of energy intake but allowed for ASF to be completely excluded from the diet (227). Indeed, a review of 56 studies of environmentally friendly diets in HICs found that all recommended lower ASF (particularly beef and pork) consumption as one way to reduce diets' environmental impacts (228), and a review of 14 dietary patterns (again in HICs) found the environmental footprint reduction to be proportional to the amount of ASF reduction (229). Dietary scenarios with the lowest ASF consumption (vegetarian and vegan) tend to perform best in terms of land use and GHG emissions (a $24-51 \%$ and $33-55 \%$ median reduction in impact for vegetarian and vegan diets, respectively) $(225,228,230-232)$, with water use being lower for vegetarian-but not necessarily vegan-diets $(224,225,228,230)$. Diets in which ruminants are replaced with other ASF show smaller reductions (224), and diets in which low-impact ASF (e.g., molluscs, insects) replace other ASF may be even lower-impact than vegetarian diets (224). All such analyses depend on certain assumptions about what substitutes for meat in vegan or vegetarian diets (i.e., minimally processed versus highly processed PSF, levels of dairy products consumed) and how finely the study distinguishes between different categories of meat; this is not always transparently communicated or directly reflective of actual consumption patterns. 
Associational studies of low-environmental-impact diets and health outcomes, primarily from HICs, have found mixed results. Semi-vegetarian, vegetarian, vegan, or pescatarian diets are sometimes associated with significantly lower mortality and/or colorectal cancer risk $(229,233)$, and PSF consumption with lower risk of type 2 diabetes and heart disease $(234,235)$. However, other analyses show limited associations between diet and disease risk (229). Modelling studies suggest that dietary shifts away from ASF could result in large decreases in diet-related mortality and morbidity $(139,232)$, though this also usually includes the positive effect of increases in minimally processed PSF consumption (particularly fruit and vegetables) and does not consider shifts solely away from the least healthy ASF (i.e., processed red meats). ${ }^{13}$
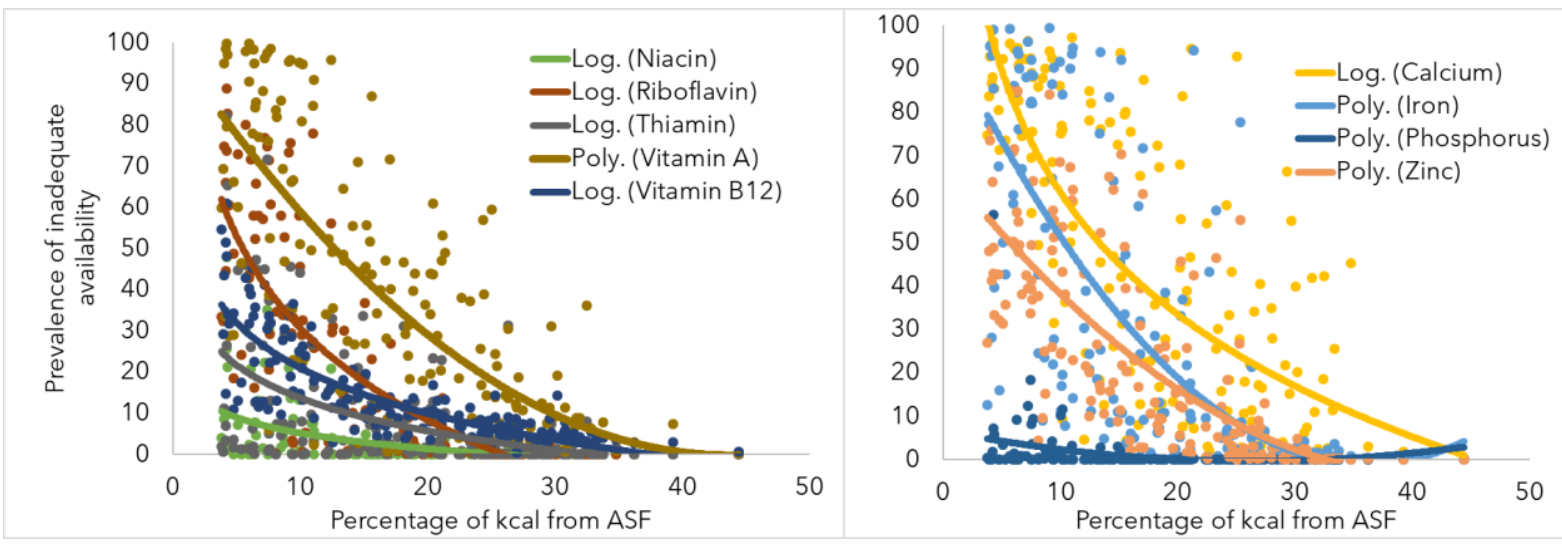

Figure 5. Relationship between percentage of energy from ASF and estimated prevalence of inadequate micronutrient availability, based on analysis of national food balance sheets for 167 countries in 2011 . For all nutrients shown, Spearman correlation coefficients were $>0.05$ and $p<0.0001$. Micronutrient adequacy estimates from (36).

While revealing, there are some gaps in these studies. Many have focused on ASF as solely a source of protein, ignoring the important micronutrients they provide; as a result, suggested diets may be deficient in key nutrients, including iron, vitamin $A$, zinc, vitamin $D$, vitamin $B_{12}$, calcium, and DHA $(239,240)$. It is essential to look more broadly when considering nutritional impacts, particularly in LMICs, given the large burdens of micronutrient deficiency. This is confirmed through observational macro-level data, as shown in Figure 5: as the percentage of energy from ASF in national food supplies increases, micronutrient density and adequacy increase, with an average of 35\% of energy from ASF required to provide a nutritionally adequate diet for the population (Engle-Stone, unpublished analysis based on (36)). While diets with no or minimal ASF can be nutritionally adequate if well designed, few if any national food supplies are currently able to support such diets for the majority of the population. Maintaining or shifting diets to be very low in ASF yet sufficient in nutrients would require considerable production and behaviour change that may be unrealistic for most countries.

\footnotetext{
${ }^{13}$ From a solely nutritional perspective, the Dietary Approaches to Stop Hypertension (DASH) diet recommends an average of $30-35 \%$ of energy from ASF (236). Evolutionary diets (for $>99 \%$ of hominin past), which were highly nutrient dense and did not contribute to chronic disease, consisted of between $30-70 \%$ of energy from ASFs $(237,238)$.
} 
Second, comparisons often consider PSF as unprocessed or minimally processed crop products; when transformed into highly processed easy-to-eat forms (e.g., meat substitutes), the environmental footprint is likely higher and the nutritional and health impacts potentially worse, though there is limited research available on this (241). Actual effects of reductions in ASF consumption on health will depend on what substitutes for ASF in the diet, be it minimally processed fruits, vegetables, legumes, and nuts, highly processed snacks, fast foods, and sugar-sweetened beverages, or something in between.

Third, reference diets usually consider the average healthy adult, not those with special nutritional needs (e.g., pregnant women, young children). Providing a special diet only for these more vulnerable household members is challenging, however, as in many cultures all household members eat the same meal, sometimes from the same plate. Finally, there has been limited study of environmental impacts other than GHG emissions and land and water use $(229,242)$, and most work has focused on HICs $(224,229)$. Greater geographic specificity is important, as the effects of dietary shifts in terms of environmental impacts and nutritional adequacy vary widely across countries $(224,232)$.

\section{DISCUSSION AND CONCLUSION}

This paper has aimed to, through a review of existing evidence, bring clarity and spark discussion on the role of animal-source foods in supporting human and environmental health and wellbeing. In so doing, we have summarised levels of ASF consumption around the world, showing them to be comparatively low in many LMICs but fairly high in most HICs. We have detailed the nutritional benefits of consuming low to moderate amounts of minimally processed ASF, which tend to be rich in nutrients not found in (or found in lowerquality forms in) PSF, noting that ASF can play a particularly important role in the diets of young children prone to undernutrition. We have also discussed the negative health consequences of high levels of consumption of processed red meat and, with less certainty, unprocessed red meat, while noting that the overall diet is more important than individual foods and that similar consequences can be seen for high levels of consumption of heavily processed PSF. We then delved into environmental aspects of ASF, showing them to generally have higher impacts than PSF in terms of GHG emissions, water and land use, biodiversity loss, and soil and water pollution; while there is considerable variation by type of ASF, production system, and context, ruminants tend to have the highest associated environmental impact. We noted several opportunities for reducing these impacts through changes in production approaches-with the caveat that these can only go so far. Finally, we emphasised the important role of ASF production in livelihoods and lifestyles in LMICs and argued that equity concerns within and among countries must be considered when discussing potential changes to production or consumption.

We acknowledge some weaknesses to our analysis. Examining these issues at a global scale, we left out considerable nuance in how they manifest locally, particularly for the environmental topics. We were reliant on synthesising pre-existing research, which used different definitions and data sources and thus was not always directly comparable. Reflecting existing research, our discussion of environmental impacts provided limited 
detail on biodiversity, soil and water pollution, or soil health. Moreover, while important, animal rights and welfare were not discussed, nor were issues related to preferences and food cultures.

At the end of this exploration, we can say with certainty that the issue of ASF consumption is complex, cutting across domains of nutrition and health, environment, livelihoods, and equity, and manifests differently in different settings (and for different individuals). The issues defy easy answers. Figure 6, below, summarises (with numerous simplifications and generalisations, and based on our own reading of the literature) this complexity. While we recognise numerous gaps, contestations, and oversimplifications in this figure, we include it because it forces us to see health, environmental, and livelihood outcomes as inextricably linked and non-separable within this debate. Moreover, it shows the vast amount of information needed to make definitive, sound policy decisions about food production and consumption; this should sober us to avoid making simplistic statements about ASF.

With these principles in mind, there are some conclusions that can be drawn. First, reducing the environmental footprint of food production whilst shrinking global burdens of ill health, undernutrition, and poverty cannot be done via a one-size-fits-all approach. Context matters. Most of the cells shown in Figure 6 (especially those on environmental and livelihood outcomes) will vary by context; when considering the policy or programmatic approach relevant in a given setting, a completed matrix like Fig. 6 (or similar) is needed to guide decisions. In particular, there is a need to consider LMICs explicitly, given the different place of animals in livelihoods and lifestyles and differences in nutrition and health issues_as well as differential responsibilities and capacities when it comes to climate change mitigation and adaptation. 


\begin{tabular}{|c|c|c|c|c|c|c|c|}
\hline & & \multicolumn{6}{|c|}{ Animal-Source Foods } \\
\hline & & \multirow{2}{*}{ Dairy } & \multirow{2}{*}{ Eggs } & \multirow{2}{*}{ Fish and Seafood } & \multicolumn{3}{|c|}{ Meat } \\
\hline & & & & & Unprocessed red & Processed red & White \\
\hline \multirow{4}{*}{$\begin{array}{l}\text { Health } \\
\text { outcomes }\end{array}$} & $\begin{array}{l}\text { Iron-deficiency } \\
\text { Anaemia }\end{array}$ & Neutral & $\begin{array}{l}\text { Slightly } \\
\text { reduces }\end{array}$ & Slightly reduces & Strongly reduces & ?? & Slightly reduces \\
\hline & $\begin{array}{l}\text { Micronutrient } \\
\text { deficiencies }\end{array}$ & Reduces & Reduces & Reduces & Reduces & ?? & Reduces \\
\hline & Stunting & Reduces & Reduces & Reduces & Reduces & ?? & Reduces \\
\hline & $\begin{array}{l}\text { Diabetes, cancer, } \\
\text { heart disease }\end{array}$ & $\begin{array}{l}\text { Likely reduces or } \\
\text { neutral, but contested }\end{array}$ & $\begin{array}{l}\text { Likely reduces } \\
\text { or neutral, but } \\
\text { contested }\end{array}$ & Reduces & $\begin{array}{l}\text { Likely increases, } \\
\text { but contested }\end{array}$ & Increases & Likely neutral \\
\hline \multirow{2}{*}{$\begin{array}{l}\text { Environ- } \\
\text { mental } \\
\text { outcomes }\end{array}$} & GHG emissions & Moderate & Moderate & $\begin{array}{l}\text { Moderate (with } \\
\text { wide range) }\end{array}$ & $\begin{array}{l}\text { High, } \\
\text { but highly variant } \\
\text { by setting/system }\end{array}$ & $\begin{array}{l}\text { High, } \\
\text { but highly variant } \\
\text { by setting/system }\end{array}$ & Moderate \\
\hline & $\begin{array}{l}\text { Other } \\
\text { environmental } \\
\text { factors }\end{array}$ & Moderate to high & Moderate & ¿?? (highly variant) & $\begin{array}{l}\text { High, } \\
\text { but highly variant } \\
\text { by setting/system }\end{array}$ & $\begin{array}{l}\text { High, } \\
\text { but highly variant } \\
\text { by setting/system }\end{array}$ & Moderate to high \\
\hline Livelihoods & $\begin{array}{l}\text { Poverty } \\
\text { reduction, } \\
\text { economic } \\
\text { development }\end{array}$ & Important & $\begin{array}{l}\text { Less important } \\
\text { (production } \\
\text { more } \\
\text { industrialised) }\end{array}$ & $\begin{array}{l}\text { Important but } \\
\text { geographically } \\
\text { concentrated }\end{array}$ & Important & ?? & $\begin{array}{l}\text { Less important } \\
\text { (production more } \\
\text { industrialised) }\end{array}$ \\
\hline
\end{tabular}

Figure 6. Summary of the health, environmental, and livelihood dimensions of ASF production and consumption. Source: authors' interpretation of the literature cited in this paper. 
With that in mind, most people in most HICs could reduce consumption of many ASF (particularly red and processed meat and dairy) with no harm to their health (and likely some benefits), were it replaced with minimally processed nutritious PSF. Were this done at scale, there would be large potential benefits for the planet. Indeed, the potential for reducing the environmental impact of the food system through consumption shifts is often largest in HICs; in the United States, for example, the removal of ASF from diets would reduce food-related emissions by $61-73 \%$ (226). HICs also have the greatest capacity to reduce consumption, given current high levels and that these countries could more readily bear the costs of such a transition, thanks to greater wealth and a smaller proportion of the population being employed in the ASF-production sector. Empowered consumers in many HICs can also seek to purchase sustainably produced ASF with lower environmental impacts.

The same is not true in most LMICs. Given the growing double burden of malnutrition (5), many wealthy and middle-income populations in LMICs may benefit from the same reductions in ASF consumption as HIC populations. Among lower-income consumers in LMICs, however, diets still tend to be highly dependent on staple foods (e.g., wheat, rice, or maize). For these people, moderately increasing consumption of un- or minimally processed ASF (in addition to consumption of minimally processed PSF, particularly nutrient-dense fruits, vegetables, and nuts/legumes) is a promising route to reducing malnutrition. Indeed, intakes of many ASF in SSA and South Asia fall far short of recommendations, even those given by 'environmentally friendly' diets recommending low ASF intake (139). Increasing minimally processed ASF consumption in these countries to meet recommended intakes would improve the nutritional adequacy of population diets and have large benefits for wellbeing. This is particularly true for nutritionally vulnerable groups, including children, adolescents, and pregnant and lactating women, for whom such ASF (and the bioavailable micronutrients they contain) can be especially important. It is also particularly true for certain types of ASF-such as many fish, the consumption of which may reduce both undernutrition and risk of diet-related NCDs.

However, increasing consumption of ASF (particularly ruminant meat and pork) in LMICs is likely to increase the environmental footprint of the food system $(170,224)$ unless accompanied by improvements in productivity and/or production practices. This could be enabled by concomitant reductions in ASF consumption in HICs (particularly in ruminant meat in North America and Europe). However, since production in HICs is more efficient, such a trade-off could not be one-to-one unless ASF production in LMICs were comparable to that in HICs in efficiency or environmental impact. Increases in livestock productivity and lower emissions intensities (including, perhaps, greater GHG sequestration) within the livestock and fisheries sectors in LMICs are thus essential; such changes could have benefits for livelihoods, nutrition, and the environment.

Second, as noted throughout this paper, it is essential to recognise the diversity of ASF (and PSF) in terms of both environmental impacts and contribution to nutrition and health. In doing so, we should avoid binary distinctions and instead choose ASF and PSF to prioritise and deprioritise smartly, based on what they add to diet and their environmental footprint.

Third, a holistic view of sustainable diets must include a strong equity lens, with particular consideration for the needs of the most vulnerable within and across countries. In doing so, 
there is a need to balance human and environmental health with economic growth and livelihoods (150). Livestock and fisheries in many LMICs make large contributions to livelihoods and income growth potential, particularly for those living in marginal areas with limited options for agriculture and for the landless. Any consideration of restructuring the food system to reduce its environmental impacts must consider the implications for livelihoods and incomes. From a perspective of procedural (as opposed to distributive) justice (212), there also should be additional involvement of LMIC citizens, across sub-national groups, in research and decision-making related to food systems transformations.

Finally, across all of these topics, we have noted numerous areas of uncertainty and scientific debate. There is thus a critical need for more research-particularly in LMICs and that jointly examines all these issues, rather than viewing them in isolation. We are far from being able to fill in all the cells in Fig. 6 for each country (and even farther for sub-national regions). Doing so in a way that can inform policy debates should be an overarching aim of food systems research going forward. With the strength of this science to guide us, we can ensure a civil, respectful discourse on the topic of animal-source foods, grounded in evidence as opposed to ideology. Doing so is crucial, given the critical importance of the issues surrounding ASF for the health and wellbeing of both people and planet. 


\section{REFERENCES}

1. UNICEF, WHO, World Bank. Levels and trends in child malnutrition: Key Findings of the 2020 Edition of the Joint Child Malnutrition Estimates. Geneva: World Health Organization; 2020.

2. Bailey RL, West Jr. KP, Black RE. The Epidemiology of Global Micronutrient Deficiencies. Ann Nutr Metab. 2015;66(2):22-33.

3. Black RE, Allen LH, Bhutta ZA, Caulfield LE, de Onis M, Ezzati M, et al. Maternal and child undernutrition: global and regional exposures and health consequences. The Lancet. 2008 Jan 19;371(9608):243-60.

4. de Onis M, Branca F. Childhood stunting: a global perspective: Childhood stunting: a global perspective. Matern Child Nutr. 2016 May;12:12-26.

5. Popkin BM, Corvalan C, Grummer-Strawn LM. Dynamics of the double burden of malnutrition and the changing nutrition reality. The Lancet. 2020 Jan;395(10217):65-74.

6. Zhou B, Lu Y, Hajifathalian K, Bentham J, Cesare MD, Danaei G, et al. Worldwide trends in diabetes since 1980: a pooled analysis of 751 population-based studies with 4.4 million participants. The Lancet. 2016 Apr 9;387(10027):1513-30.

7. WHO. Global report on diabetes. Geneva: World Health Organization; 2016.

8. Bhutta ZA, Das JK, Rizvi A, Gaffey MF, Walker N, Horton S, et al. Evidence-based interventions for improvement of maternal and child nutrition: what can be done and at what cost? Lancet Lond Engl. 2013 Aug 3;382(9890):452-77.

9. Walker SP, Wachs TD, Grantham-McGregor S, Black MM, Nelson CA, Huffman SL, et al. Inequality in early childhood: risk and protective factors for early child development. The Lancet. 2011 Oct 8;378(9799):1325-38.

10. Grantham-McGregor S, Cheung YB, Cueto S, Glewwe P, Richter L, Strupp B, et al. Developmental potential in the first 5 years for children in developing countries. Lancet Lond Engl. 2007 Jan 6;369(9555):60-70.

11. Black RE, Victora CG, Walker SP, Bhutta ZA, Christian P, de Onis M, et al. Maternal and child undernutrition and overweight in low-income and middle-income countries. The Lancet. 2013 Aug;382(9890):427-51.

12. Afshin A, Sur PJ, Fay KA, Cornaby L, Ferrara G, Salama JS, et al. Health effects of dietary risks in 195 countries, 1990-2017: a systematic analysis for the Global Burden of Disease Study 2017. The Lancet. 2019 May 11;393(10184):1958-72.

13. Lenton TM, Rockström J, Gaffney O, Rahmstorf S, Richardson K, Steffen W, et al. Climate tipping points — too risky to bet against. Nature. 2019 Nov;575(7784):592-5.

14. Field C, Barros V, Mach K, Mastrandrea M, van Aalst M, Adger WN, et al. Technical Summary. In: Climate Change 2014:Impacts, Adaptation, and Vulnerability Part A: Global and Sectoral Aspects Contribution of Working Group II to the Fifth Assessment Report of the 
Intergovernmental Panel on Climate Change. Cambridge and New York: Cambridge University Press; 2014. p. 35-94.

15. Myers SS, Zanobetti A, Kloog I, Huybers P, Leakey ADB, Bloom AJ, et al. Increasing CO2 threatens human nutrition. Nature. 2014 Jun;510(7503):139-42.

16. UNEP. Emissions Gap Report 2019: Executive Summary. Nairobi: United Nations Environment Programme (UNEP);

17. FAO. Water pollution from agriculture: a global review. Rome: Food and Agriculture Organization of the United Nations; 2017.

18. Unesco, World Water Assessment Programme (United Nations), UN-Water. Leaving no one behind: the United Nations World Water Development Report 2019. 2019.

19. ISPBES. Global assessment report on biodiversity and ecosystem services of the Intergovernmental Science-Policy Platform on Biodiversity and Ecosystem Services. Bonn: Intergovernmental Science-Policy Platform on Biodiversity and Ecosystem Services; 2019.

20. Enahoro D, Lannerstad M, Pfeifer C, Dominguez-Salas P. Contributions of livestockderived foods to nutrient supply under changing demand in low- and middle-income countries. Glob Food Secur. 2018 Dec 1;19:1-10.

21. Thornton PK. Livestock production: recent trends, future prospects. Philos Trans R Soc B Biol Sci. 2010 Sep 27;365(1554):2853-67.

22. Alexandratos N, Bruinsma J. World Agriculture Towards 2030/2050: The 2012 Revision. Rome: Food and Agriculture Organization of the United Nations; 2012.

23. Godfray HCJ, Aveyard P, Garnett T, Hall JW, Key TJ, Lorimer J, et al. Meat consumption, health, and the environment. Science. 2018 Jul 20;361(6399).

24. Pelletier N, Tyedmers P. Forecasting potential global environmental costs of livestock production 2000-2050. Proc Natl Acad Sci. 2010 Oct 26;107(43):18371.

25. Development Initiatives. Global Nutrition Report: Shining a light to spur action on nutrition. [Internet]. Bristol, UK: Development Initiatives; 2018. Available from: https://globalnutritionreport.org/reports/global-nutrition-report-2018/

26. Abarca-Gómez L, Abdeen ZA, Hamid ZA, Abu-Rmeileh NM, Acosta-Cazares B, Acuin $C$, et al. Worldwide trends in body-mass index, underweight, overweight, and obesity from 1975 to 2016: a pooled analysis of 2416 population-based measurement studies in 128.9 million children, adolescents, and adults. The Lancet. 2017 Dec 16;390(10113):2627-42.

27. UNICEF. The State of the World's Children 2019. Children, Food and Nutrition: Growing well in a changing world. [Internet]. New York: UNICEF; 2019. Available from: https://www.unicef.org/reports/state-of-worlds-children-2019

28. Bennett JE, Stevens GA, Mathers CD, Bonita R, Rehm J, Kruk ME, et al. NCD Countdown 2030: worldwide trends in non-communicable disease mortality and progress towards Sustainable Development Goal target 3.4. The Lancet. $2018 \mathrm{Sep}$ 22;392(10152):1072-88. 
29. Gouda HN, Charlson F, Sorsdahl K, Ahmadzada S, Ferrari AJ, Erskine H, et al. Burden of non-communicable diseases in sub-Saharan Africa, 1990-2017: results from the Global Burden of Disease Study 2017. Lancet Glob Health. 2019 Oct 1;7(10):e1375-87.

30. Baraldi LG, Martinez Steele E, Canella DS, Monteiro CA. Consumption of ultraprocessed foods and associated sociodemographic factors in the USA between 2007 and 2012: evidence from a nationally representative cross-sectional study. BMJ Open. 2018 Mar 9;8(3):e020574.

31. Canella DS, Levy RB, Martins APB, Claro RM, Moubarac J-C, Baraldi LG, et al. Ultraprocessed food products and obesity in Brazilian households (2008-2009). PloS One. 2014;9(3):e92752.

32. Popkin BM. Global nutrition dynamics: the world is shifting rapidly toward a diet linked with noncommunicable diseases. Am J Clin Nutr. 2006 Aug 1;84(2):289-98.

33. Popkin BM, Adair LS, Ng SW. Global nutrition transition and the pandemic of obesity in developing countries. Nutr Rev. 2012 Jan;70(1):3-21.

34. Monteiro CA, Levy RB, Claro RM, de Castro IRR, Cannon G. Increasing consumption of ultra-processed foods and likely impact on human health: evidence from Brazil. Public Health Nutr. 2011 Jan;14(1):5-13.

35. Murphy SP, Allen LH. Nutritional Importance of Animal Source Foods. J Nutr. 2003 Nov 1;133(11):3932S-3935S.

36. Beal T, Massiot E, Arsenault JE, Smith MR, Hijmans RJ. Global trends in dietary micronutrient supplies and estimated prevalence of inadequate intakes. PloS One. 2017;12(4):e0175554.

37. Semba RD, Shardell M, Sakr Ashour FA, Moaddel R, Trehan I, Maleta KM, et al. Child Stunting is Associated with Low Circulating Essential Amino Acids. EBioMedicine. $2016 \mathrm{Apr}$ $1 ; 6: 246-52$.

38. Neumann C, Harris DM, Rogers LM. Contribution of animal source foods in improving diet quality and function in children in the developing world. Prev Nutr. 2002 Jan 1;22(1):193-220.

39. Bender A. Meat and Meat Products in Human Nutrition in the Developing World. Rome: Food and Agriculture Organization of the United Nations; 1992. Report No.: Food and Nutrition paper No. 53.

40. Black MM. Effects of Vitamin B12 and Folate Deficiency on Brain Development in Children. Food Nutr Bull. 2008 Jun 1;29(2_suppl1):S126-31.

41. Dror DK, Allen LH. Effect of vitamin B12 deficiency on neurodevelopment in infants: current knowledge and possible mechanisms. Nutr Rev. 2008 May 1;66(5):250-5.

42. Holick MF, Chen TC. Vitamin D deficiency: a worldwide problem with health consequences. Am J Clin Nutr. 2008 Apr 1;87(4):1080S-1086S. 
43. Gibson RS, Perlas L, Hotz C. Improving the bioavailability of nutrients in plant foods at the household level. Proc Nutr Soc. 2006 May;65(2):160-8.

44. Semrad CE. Zinc and intestinal function. Curr Gastroenterol Rep. 1999 Oct 1;1(5):398403.

45. Black MM. Zinc deficiency and child development. Am J Clin Nutr. 1998 Aug;68(2 Suppl):464S-469S.

46. Tang G. Bioconversion of dietary provitamin A carotenoids to vitamin A in humans. Am J Clin Nutr. 2010 May 1;91(5):1468S-1473S.

47. Sommer A, World Health Organization. Vitamin A deficiency and its consequences: a field guide to detection and control [Internet]. World Health Organization; 1995 [cited 2019 Nov 21]. Available from: https://apps.who.int/iris/handle/10665/40535

48. Hallberg L, Björn-Rasmussen E, Howard L, Rossander L. Dietary Heme Iron Absorption. Scand J Gastroenterol. 1979 Oct 1;14(7):769-79.

49. Balder HF, Vogel J, Jansen MCJF, Weijenberg MP, Brandt PA van den, Westenbrink $S$, et al. Heme and Chlorophyll Intake and Risk of Colorectal Cancer in the Netherlands Cohort Study. Cancer Epidemiol Biomarkers Prev. 2006 Apr 1;15(4):717-25.

50. Pourkhalili A, Mirlohi M, Rahimi E. Heme Iron Content in Lamb Meat Is Differentially Altered upon Boiling, Grilling, or Frying as Assessed by Four Distinct Analytical Methods. Sci World J. 2013 May 8;2013:e374030.

51. Stoltzfus RJ. Iron Deficiency: Global Prevalence and Consequences. Food Nutr Bull. 2003 Jan 1;24(4_suppl_1):S99-103.

52. Young VR, Pellett PL. Plant proteins in relation to human protein and amino acid nutrition. Am J Clin Nutr. 1994 May 1;59(5):1203S-1212S.

53. Swanson D, Block R, Mousa SA. Omega-3 Fatty Acids EPA and DHA: Health Benefits Throughout Life. Adv Nutr. 2012 Jan 1;3(1):1-7.

54. USDA. FoodData Central Database [Internet]. U.S. Department of Agriculture, Agricultural Research Service; 2019. Available from: https://fdc.nal.usda.gov

55. Dewey KG. Nutrition, Growth, and Complementary Feeding of The Brestfed Infant. Pediatr Clin North Am. 2001 Feb;48(1):87-104.

56. WHO. World health assembly global nutrition targets 2025: stunting policy brief [Internet]. Geneva: World Health Organization; 2014. Available from:

http://www.who.int/nutrition/topics/globaltargets_stunting_policybrief.pdf

57. Krebs NF, Mazariegos M, Tshefu A, Bose C, Sami N, Chomba E, et al. Meat consumption is associated with less stunting among toddlers in four diverse low-income settings. Food Nutr Bull. 2011 Sep;32(3):185-91.

58. Dror DK, Allen LH. The Importance of Milk and other Animal-Source Foods for Children in Low-Income Countries. Food Nutr Bull. 2011 Sep 1;32(3):227-43. 
59. Headey DD, Hirvonen K, Hoddinott J. Animal Sourced Foods and Child Stunting. Washington, DC: International Food Policy Research Institute (IFPRI); Report No.: IFPRI Discussion Paper 01695.

60. Neumann CG, Bwibo NO, Murphy SP, Sigman M, Whaley S, Allen LH, et al. Animal Source Foods Improve Dietary Quality, Micronutrient Status, Growth and Cognitive Function in Kenyan School Children: Background, Study Design and Baseline Findings. J Nutr. 2003 Nov 1;133(11):3941S-3949S.

61. Iannotti LL, Lutter CK, Stewart CP, Gallegos Riofrío CA, Malo C, Reinhart G, et al. Eggs in Early Complementary Feeding and Child Growth: A Randomized Controlled Trial. Pediatrics. 2017 Jul 1;140(1):e20163459.

62. Mahfuz M, Alam MA, Das S, Fahim SM, Hossain MS, Petri Jr WA, et al. Daily Supplementation With Egg, Cow Milk, and Multiple Micronutrients Increases Linear Growth of Young Children with Short Stature. J Nutr [Internet]. [cited 2019 Nov 26]; Available from: https://academic.oup.com/jn/advance-article/doi/10.1093/jn/nxz253/5607415

63. Stewart CP, Caswell B, lannotti L, Lutter C, Arnold CD, Chipatala R, et al. The effect of eggs on early child growth in rural Malawi: the Mazira Project randomized controlled trial. Am J Clin Nutr. 2019 Aug 6;110(4):1026-33.

64. Osendarp SJM, Broersen B, van Liere MJ, De-Regil LM, Bahirathan L, Klassen E, et al. Complementary Feeding Diets Made of Local Foods Can Be Optimized, but Additional Interventions Will Be Needed to Meet Iron and Zinc Requirements in 6- to 23-Month-Old Children in Low- and Middle-Income Countries. Food Nutr Bull. 2016 Dec;37(4):544-70.

65. Eaton J, Rothpletz-Puglia P, Dreker M, lannotti L, Lutter C, Kaganda J, et al. Effectiveness of provision of animal-source foods for supporting optimal growth and development in children 6 to 59 months of age. Cochrane Database Syst Rev [Internet]. 2019;(2). Available from: https://doi.org//10.1002/14651858.CD012818.pub2

66. Shapiro MJ, Downs SM, Swartz HJ, Parker M, Quelhas D, Kreis K, et al. A Systematic Review Investigating the Relation Between Animal-Source Food Consumption and Stunting in Children Aged 6-60 Months in Low and Middle-Income Countries. Adv Nutr. 2019 Jun 8;10(5):827-47.

67. Pimpin L, Kranz S, Liu E, Shulkin M, Karageorgou D, Miller V, et al. Effects of animal protein supplementation of mothers, preterm infants, and term infants on growth outcomes in childhood: a systematic review and meta-analysis of randomized trials. Am J Clin Nutr. 2019 Aug 1;110(2):410-29.

68. Kim JH, Kim Y, Kim YJ, Park Y. Conjugated Linoleic Acid: Potential Health Benefits as a Functional Food Ingredient. Annu Rev Food Sci Technol. 2016;7(1):221-44.

69. Bhat ZF, Kumar S, Bhat HF. Bioactive peptides of animal origin: a review. J Food Sci Technol. 2015 Sep 1;52(9):5377-92.

70. Tang M. Protein Intake during the First Two Years of Life and Its Association with Growth and Risk of Overweight. Int J Environ Res Public Health. 2018 Aug;15(8):1742. 
71. Levine ME, Suarez JA, Brandhorst S, Balasubramanian P, Cheng C-W, Madia F, et al. Low Protein Intake is Associated with a Major Reduction in IGF-1, Cancer, and Overall Mortality in the 65 and Younger but Not Older Population. Cell Metab. 2014 Mar 4;19(3):407-17.

72. Hooper L, Martin N, Abdelhamid A, Davey Smith G. Reduction in saturated fat intake for cardiovascular disease. Cochrane Heart Group, editor. Cochrane Database Syst Rev [Internet]. 2015 Jun 10 [cited 2019 Jul 8]; Available from:

http://doi.wiley.com/10.1002/14651858.CD011737

73. Thornley S, Schofield G, Zinn C, Henderson G. How reliable is the statistical evidence for limiting saturated fat intake? A fresh look at the influential Hooper meta-analysis. Intern Med J. 2019;49(11):1418-24.

74. Mozaffarian D, Micha R, Wallace S. Effects on Coronary Heart Disease of Increasing Polyunsaturated Fat in Place of Saturated Fat: A Systematic Review and Meta-Analysis of Randomized Controlled Trials. Katan MB, editor. PLoS Med. 2010 Mar 23;7(3):e1000252.

75. Mensink RP. Effects of saturated fatty acids on serum lipids and lipoproteins: a systematic review and regression analysis. 2016;

76. Astrup A, Bertram HC, Bonjour J-P, Groot LC de, Otto MC de O, Feeney EL, et al. WHO draft guidelines on dietary saturated and trans fatty acids: time for a new approach? BMJ. 2019 Jul 3;366:14137.

77. Mozaffarian D. Dietary and Policy Priorities for Cardiovascular Disease, Diabetes, and Obesity: A Comprehensive Review. Circulation. 2016 Jan 12;133(2):187-225.

78. Shih CW, Hauser ME, Aronica L, Rigdon J, Gardner CD. Changes in blood lipid concentrations associated with changes in intake of dietary saturated fat in the context of a healthy low-carbohydrate weight-loss diet: a secondary analysis of the Diet Intervention Examining The Factors Interacting with Treatment Success (DIETFITS) trial. Am J Clin Nutr. 2019 Feb 1;109(2):433-41.

79. Ramsden CE, Zamora D, Majchrzak-Hong S, Faurot KR, Broste SK, Frantz RP, et al. Reevaluation of the traditional diet-heart hypothesis: analysis of recovered data from Minnesota Coronary Experiment (1968-73). BMJ. 2016 Apr 12;11246.

80. Hamley S. The effect of replacing saturated fat with mostly $n-6$ polyunsaturated fat on coronary heart disease: a meta-analysis of randomised controlled trials. Nutr J. 2017 Dec;16(1):30.

81. Chowdhury R, Warnakula S, Kunutsor S, Crowe F, Ward HA, Johnson L, et al. Association of Dietary, Circulating, and Supplement Fatty Acids With Coronary Risk: A Systematic Review and Meta-analysis. Ann Intern Med. 2014 Mar 18;160(6):398.

82. de Souza RJ, Mente A, Maroleanu A, Cozma Al, Ha V, Kishibe T, et al. Intake of saturated and trans unsaturated fatty acids and risk of all cause mortality, cardiovascular disease, and type 2 diabetes: systematic review and meta-analysis of observational studies. BMJ. 2015 Aug 11;h3978. 
83. Siri-Tarino PW, Sun Q, Hu FB, Krauss RM. Meta-analysis of prospective cohort studies evaluating the association of saturated fat with cardiovascular disease. Am J Clin Nutr. 2010 Mar 1;91(3):535-46.

84. Dehghan M, Mente A, Zhang X, Swaminathan S, Li W, Mohan V, et al. Associations of fats and carbohydrate intake with cardiovascular disease and mortality in 18 countries from five continents (PURE): a prospective cohort study. The Lancet. 2017 Nov 4;390(10107):2050 62.

85. Mente A, Dehghan M, Rangarajan S, McQueen M, Dagenais G, Wielgosz A, et al. Association of dietary nutrients with blood lipids and blood pressure in 18 countries: a crosssectional analysis from the PURE study. Lancet Diabetes Endocrinol. 2017 Oct 1;5(10):77487.

86. Kim JE, Campbell WW. Dietary Cholesterol Contained in Whole Eggs Is Not Well Absorbed and Does Not Acutely Affect Plasma Total Cholesterol Concentration in Men and Women: Results from 2 Randomized Controlled Crossover Studies. Nutrients. 2018 Sep;10(9):1272.

87. Rong Y, Chen L, Zhu T, Song Y, Yu M, Shan Z, et al. Egg consumption and risk of coronary heart disease and stroke: dose-response meta-analysis of prospective cohort studies. The BMJ [Internet]. 2013 Jan 7 [cited 2019 Nov 22];346. Available from: https://www.ncbi.nlm.nih.gov/pmc/articles/PMC3538567/

88. $\mathrm{Xu} \mathrm{L}$, Lam TH, Jiang CQ, Zhang WS, Zhu F, Jin YL, et al. Egg consumption and the risk of cardiovascular disease and all-cause mortality: Guangzhou Biobank Cohort Study and meta-analyses. Eur J Nutr. 2019 Mar 1;58(2):785-96.

89. Marventano S, Godos J, Tieri M, Ghelfi F, Titta L, Lafranconi A, et al. Egg consumption and human health: an umbrella review of observational studies. Int J Food Sci Nutr. 2019 Aug 5;0(0):1-7.

90. Berger S, Raman G, Vishwanathan R, Jacques PF, Johnson EJ. Dietary cholesterol and cardiovascular disease: a systematic review and meta-analysis. Am J Clin Nutr. 2015 Aug $1 ; 102(2): 276-94$.

91. Mah E, Chen C-YO, Liska DJ. The effect of egg consumption on cardiometabolic health outcomes: an umbrella review. Public Health Nutr. 2019;1-21.

92. Wang Z, Bergeron N, Levison BS, Li XS, Chiu S, Jia X, et al. Impact of chronic dietary red meat, white meat, or non-meat protein on trimethylamine $\mathrm{N}$-oxide metabolism and renal excretion in healthy men and women. Eur Heart J. 2019 Feb 14;40(7):583-94.

93. Cho CE, Taesuwan S, Malysheva OV, Bender E, Tulchinsky NF, Yan J, et al. Trimethylamine-N-oxide (TMAO) response to animal source foods varies among healthy young men and is influenced by their gut microbiota composition: A randomized controlled trial. Mol Nutr Food Res. 2017;61(1):1600324.

94. Zhang AQ, Mitchell SC, Smith RL. Dietary Precursors of Trimethylamine in Man: A Pilot Study. Food Chem Toxicol. 1999 May 1;37(5):515-20. 
95. Miller CA, Corbin KD, da Costa K-A, Zhang S, Zhao X, Galanko JA, et al. Effect of egg ingestion on trimethylamine- $\mathrm{N}$-oxide production in humans: a randomized, controlled, doseresponse study. Am J Clin Nutr. 2014 Sep 1;100(3):778-86.

96. Missimer A, Fernandez ML, DiMarco DM, Norris GH, Blesso CN, Murillo AG, et al. Compared to an Oatmeal Breakfast, Two Eggs/Day Increased Plasma Carotenoids and Choline without Increasing Trimethyl Amine N-Oxide Concentrations. J Am Coll Nutr. 2018 Feb 17;37(2):140-8.

97. Rimm Eric B., Appel Lawrence J., Chiuve Stephanie E., Djoussé Luc, Engler Mary B., Kris-Etherton Penny M., et al. Seafood Long-Chain n-3 Polyunsaturated Fatty Acids and Cardiovascular Disease: A Science Advisory From the American Heart Association. Circulation. 2018 Jul 3;138(1):e35-47.

98. Fang X, An P, Wang H, Wang X, Shen X, Li X, et al. Dietary intake of heme iron and risk of cardiovascular disease: A dose-response meta-analysis of prospective cohort studies. Nutr Metab Cardiovasc Dis. 2015 Jan 1;25(1):24-35.

99. Etemadi A, Sinha R, Ward MH, Graubard BI, Inoue-Choi M, Dawsey SM, et al. Mortality from different causes associated with meat, heme iron, nitrates, and nitrites in the NIH-AARP Diet and Health Study: population based cohort study. The BMJ [Internet]. 2017 May 9 [cited 2019 Nov 22];357. Available from:

https://www.ncbi.nlm.nih.gov/pmc/articles/PMC5423547/

100. Yang $W$, Li B, Dong $X$, Zhang $X-Q$, Zeng $Y$, Zhou J-L, et al. Is heme iron intake associated with risk of coronary heart disease? A meta-analysis of prospective studies. Eur $\mathrm{J}$ Nutr. 2014 Mar 1;53(2):395-400.

101. Hooda J, Shah A, Zhang L. Heme, an Essential Nutrient from Dietary Proteins, Critically Impacts Diverse Physiological and Pathological Processes. Nutrients. 2014 Mar 13;6(3):1080-102.

102. Schar D, Sommanustweechai A, Laxminarayan R, Tangcharoensathien V. Surveillance of antimicrobial consumption in animal production sectors of low- and middle-income countries: Optimizing use and addressing antimicrobial resistance. PLOS Med. 2018 Mar 1;15(3):e1002521.

103. Hedberg N, Stenson I, Nitz Pettersson M, Warshan D, Nguyen-Kim H, Tedengren M, et al. Antibiotic use in Vietnamese fish and lobster sea cage farms; implications for coral reefs and human health. Aquaculture. 2018 Oct 1;495:366-75.

104. Laxminarayan R, Duse A, Wattal C, Zaidi AKM, Wertheim HFL, Sumpradit N, et al. Antibiotic resistance — the need for global solutions. Lancet Infect Dis. 2013 Dec 1;13(12):1057-98.

105. Kabir ER, Rahman MS, Rahman I. A review on endocrine disruptors and their possible impacts on human health. Environ Toxicol Pharmacol. 2015 Jul 1;40(1):241-58.

106. Mente A, O'Donnell M, Rangarajan S, McQueen M, Dagenais G, Wielgosz A, et al. Urinary sodium excretion, blood pressure, cardiovascular disease, and mortality: a 
community-level prospective epidemiological cohort study. The Lancet. 2018 Aug 11;392(10146):496-506.

107. Graudal NA, Hubeck-Graudal T, Jurgens G. Effects of low sodium diet versus high sodium diet on blood pressure, renin, aldosterone, catecholamines, cholesterol, and triglyceride. Cochrane Database Syst Rev [Internet]. 2017 [cited 2019 Nov 22];(4). Available from: https://www.cochranelibrary.com/cdsr/doi/10.1002/14651858.CD004022.pub4/full

108. Mente A, O'Donnell M, Rangarajan S, Dagenais G, Lear S, McQueen M, et al. Associations of urinary sodium excretion with cardiovascular events in individuals with and without hypertension: a pooled analysis of data from four studies. The Lancet. $2016 \mathrm{Jul}$ 30;388(10043):465-75.

109. Hord NG, Conley MN. Regulation of Dietary Nitrate and Nitrite: Balancing Essential Physiological Roles with Potential Health Risks. In: Bryan NS, Loscalzo J, editors. Nitrite and Nitrate in Human Health and Disease [Internet]. Cham: Springer International Publishing; 2017 [cited 2019 Nov 22]. p. 153-62. (Nutrition and Health). Available from: https://doi.org/10.1007/978-3-319-46189-2_12

110. Micha R, Wallace SK, Mozaffarian D. Red and processed meat consumption and risk of incident coronary heart disease, stroke, and diabetes: A systematic review and meta-analysis. Circulation. 2010 Jun 1;121(21):2271-83.

111. Rohrmann S, Linseisen J. Processed meat: the real villain? Proc Nutr Soc. 2016 Aug;75(3):233-41.

112. Alexander DD, Miller AJ, Cushing CA, Lowe KA. Processed meat and colorectal cancer: a quantitative review of prospective epidemiologic studies. Eur J Cancer Prev Off J Eur Cancer Prev Organ ECP. 2010 Sep;19(5):328-41.

113. Johnston BC, Zeraatkar D, Han MA, Vernooij RWM, Valli C, El Dib R, et al. Unprocessed Red Meat and Processed Meat Consumption: Dietary Guideline Recommendations From the Nutritional Recommendations (NutriRECS) Consortium. Ann Intern Med [Internet]. 2019 Oct 1 [cited 2019 Nov 11]; Available from: https://doi.org/10.7326/M19-1621

114. Cross AJ, Sinha R. Meat-related mutagens/carcinogens in the etiology of colorectal cancer. Environ Mol Mutagen. 2004;44(1):44-55.

115. Góngora VM, Matthes KL, Castaño PR, Linseisen J, Rohrmann S. Dietary Heterocyclic Amine Intake and Colorectal Adenoma Risk: A Systematic Review and Meta-analysis. Cancer Epidemiol Prev Biomark. 2019 Jan 1;28(1):99-109.

116. Farhadian A, Jinap S, Abas F, Sakar ZI. Determination of polycyclic aromatic hydrocarbons in grilled meat. Food Control. 2010 May 1;21(5):606-10.

117. Bouvard V, Loomis D, Guyton KZ, Grosse Y, Ghissassi FE, Benbrahim-Tallaa L, et al. Carcinogenicity of consumption of red and processed meat. Lancet Oncol. 2015 Dec 1;16(16):1599-600. 
118. Walker P, Rhubart-Berg P, McKenzie S, Kelling K, Lawrence RS. Public health implications of meat production and consumption. Public Health Nutr. 2005;8(4):348-56.

119. Cui K, Liu Y, Zhu L, Mei X, Jin P, Luo Y. Association between intake of red and processed meat and the risk of heart failure: a meta-analysis. BMC Public Health. 2019 Mar 29;19(1):354-354.

120. Rong Y, Chen L, Zhu T, Song Y, Yu M, Shan Z, et al. Egg consumption and risk of coronary heart disease and stroke: dose-response meta-analysis of prospective cohort studies. BMJ. 2013 Jan 7;346(jan07 2):e8539-e8539.

121. Marventano S, Godos J, Tieri M, Ghelfi F, Titta L, Lafranconi A, et al. Egg consumption and human health: an umbrella review of observational studies. Int J Food Sci Nutr. 2019 Aug 5;1-7.

122. Mozaffarian D. Dairy Foods, Obesity, and Metabolic Health: The Role of the Food Matrix Compared with Single Nutrients. Adv Nutr. 2019 Sep 1;10(5):917S-923S.

123. Soedamah-Muthu SS, de Goede J. Dairy Consumption and Cardiometabolic Diseases: Systematic Review and Updated Meta-Analyses of Prospective Cohort Studies. Curr Nutr Rep. 2018 Dec;7(4):171-82.

124. Bhupathi V, Mazariegos M, Cruz Rodriguez JB, Deoker A. Dairy Intake and Risk of Cardiovascular Disease. Curr Cardiol Rep. 2020 Mar;22(3):11.

125. Calder PC. Marine omega-3 fatty acids and inflammatory processes: Effects, mechanisms and clinical relevance. Oxyg Metab PUFA Anal Biol Relev. $2015 \mathrm{Apr}$ 1;1851(4):469-84.

126. Kawarazuka N. The Contribution of Fish Intake, Aquaculture, and Small-scale Fisheries to Improving Nutrition: A Literature Review. 2010.

127. Liu RH. Health-promoting components of fruits and vegetables in the diet. Adv Nutr Bethesda Md. 2013 May 1;4(3):384S-92S.

128. Mielgo-Ayuso J, Valtueña J, Huybrechts I, Breidenassel C, Cuenca-García M, De Henauw $S$, et al. Fruit and vegetables consumption is associated with higher vitamin intake and blood vitamin status among European adolescents. Eur J Clin Nutr. $2017 \mathrm{Apr}$ $1 ; 71(4): 458-67$.

129. Hu FB. Resolved: there is sufficient scientific evidence that decreasing sugarsweetened beverage consumption will reduce the prevalence of obesity and obesity-related diseases. Obes Rev Off J Int Assoc Study Obes. 2013 Aug;14(8):606-19.

130. Melaku YA, Temesgen AM, Deribew A, Tessema GA, Deribe K, Sahle BW, et al. The impact of dietary risk factors on the burden of non-communicable diseases in Ethiopia: findings from the Global Burden of Disease study 2013. Int J Behav Nutr Phys Act. 2016 Dec $16 ; 13(1): 122-122$.

131. Marlatt KL, Farbakhsh K, Dengel DR, Lytle LA. Breakfast and fast food consumption are associated with selected biomarkers in adolescents. Prev Med Rep. 2016 Jun;3:49-52. 
132. FAO. The State of World Fisheries and Aquaculture 2018 - Meeting the sustainable development goals. Rome: Food and Agriculture Organization of the United Nations; 2018.

133. Weston $P$, Hong $R$, Kaboré $C$, Kull CA. Farmer-Managed Natural Regeneration Enhances Rural Livelihoods in Dryland West Africa. Environ Manage. 2015 Jun 1;55(6):140217.

134. Elevitch CR, Mazaroli DN, Ragone D. Agroforestry Standards for Regenerative Agriculture. Sustainability. 2018 Sep;10(9):3337.

135. Steinfeld H, Gerber P, Wassenaar TD, Rosales M, M MR, Haan C de. Livestock's Long Shadow: Environmental Issues and Options. Food and Agriculture Organization; 2006. 418 p.

136. Herrero M, Wirsenius S, Henderson B, Rigolot C, Thornton P, Havlík P, et al. Livestock and the Environment: What Have We Learned in the Past Decade? Annu Rev Environ Resour. 2015 Nov 4;40(1):177-202.

137. de Vries M, de Boer IJM. Comparing environmental impacts for livestock products: A review of life cycle assessments. Livest Sci. 2010 Mar 1;128(1):1-11.

138. Clark M, Tilman D. Comparative analysis of environmental impacts of agricultural production systems, agricultural input efficiency, and food choice. Environ Res Lett. 2017 Jun;12(6):064016.

139. Willett W, Rockström J, Loken B, Springmann M, Lang T, Vermeulen S, et al. Food in the Anthropocene: the EAT-Lancet Commission on healthy diets from sustainable food systems. The Lancet. 2019 Feb 2;393(10170):447-92.

140. FAO. The State of Food and Agriculture 2009: Livestock in the Balance. Rome: Food and Agriculture Organization of the United Nations; 2009.

141. Mottet A, de Haan C, Falcucci A, Tempio G, Opio C, Gerber P. Livestock: On our plates or eating at our table? A new analysis of the feed/food debate. Food Secur Gov Lat Am. 2017 Sep 1;14:1-8.

142. Foley JA, DeFries R, Asner GP, Barford C, Bonan G, Carpenter SR, et al. Global Consequences of Land Use. Science. 2005 Jul 22;309(5734):570-4.

143. Jones PG, Thornton PK. Croppers to livestock keepers: livelihood transitions to 2050 in Africa due to climate change. Spec Issue Food Secur Environ Change. 2009 Jun $1 ; 12(4): 427-37$.

144. Sy VD, Herold M, Achard F, Beuchle R, Clevers JGPW, Lindquist E, et al. Land use patterns and related carbon losses following deforestation in South America. Environ Res Lett. 2015 Nov;10(12):124004.

145. Smith P, Gregory PJ, van Vuuren D, Obersteiner M, Havlík P, Rounsevell M, et al. Competition for land. Philos Trans R Soc B Biol Sci. 2010 Sep 27;365(1554):2941-57.

146. Herrero M, Thornton PK, Gerber P, Reid RS. Livestock, livelihoods and the environment: understanding the trade-offs. Curr Opin Environ Sustain. 2009 Dec 1;1(2):11120. 
147. Barange M, Bahri T, Beveridge M, Cochrane K, Funge-Smith S, Poulain F. Impacts of climate change on fisheries and aquaculture: synthesis of current knowledge, adaptation and mitigation options. Rome: Food and Agriculture Organization of the United Nations; 2018 p. 628. Report No.: FAO Fisheries and Aquaculture Technical Paper No. 627.

148. Mekonnen MM, Hoekstra AY. A Global Assessment of the Water Footprint of Farm Animal Products. Ecosystems. 2012 Apr 1;15(3):401-15.

149. Peden D, Tadesse G, Misra AK, Ahmed FA, Astatke A, Ayalneh W, et al. Water and livestock for human development [Internet]. International Water Management Institute; 2007 [cited 2019 Dec 2]. (IWMI Books, Reports). Report No.: H040205. Available from: https://ideas.repec.org/p/iwt/bosers/h040205.html

150. Herrero M, Grace D, Njuki J, Johnson N, Enahoro D, Silvestri S, et al. The roles of livestock in developing countries. animal. 2013;7(s1):3-18.

151. Ran Y, van Middelaar CE, Lannerstad M, Herrero M, de Boer IJM. Freshwater use in livestock production-To be used for food crops or livestock feed? Agric Syst. 2017 Jul $1 ; 155: 1-8$.

152. Rosegrant MW, Cai X, Cline SA. Global Water Outlook To 2025: Averting an Impending Crisis [Internet]. Washington, DC: International Food Policy Research Institute (IFPRI); [cited 2019 Dec 2]. Available from:

https://www.scribd.com/document/34982256/fprwater2025

153. Smith $\mathrm{P}$, Bustamante $\mathrm{M}$, Ahammad H, Clark H, Dong H, Elsiddig $\mathrm{H}$, et al. Agriculture, Forestry and Other Land Use (AFOLU). In: Climate Change 2014: Mitigation of Climate Change Contribution of Working Group III to the Fifth Assessment Report of the Intergovernmental Panel on Climate Change. Cambridge and New York: Cambridge University Press; 2014.

154. Gerber P, Steinfeld H, Henderson B, Mottet A, Opio C, Dijkman J, et al. Tackling climate change through livestock - A global assessment of emissions and mitigation opportunities. Rome: Food and Agriculture Organization of the United Nations; 2013.

155. O'Mara FP. The significance of livestock as a contributor to global greenhouse gas emissions today and in the near future. Spec Issue Greenh Gases Anim Agric - Find Balance Food Emiss. 2011 Jun 23;166-167:7-15.

156. Havlik P, Valin H, Herrero M, Obersteiner M, Schmid E, Rufino MC, et al. Climate change mitigation through livestock system transitions. Proc Natl Acad Sci U S A. 2014 Mar $11 ; 111(10): 3709-14$.

157. Pitesky ME, Stackhouse KR, Mitloehner FM. Clearing the Air. In: Advances in Agronomy [Internet]. Elsevier; 2009 [cited 2020 Jan 3]. p. 1-40. Available from: https://linkinghub.elsevier.com/retrieve/pii/S0065211309030016

158. US EPA. Understanding Global Warming Potentials [Internet]. US Environmental Protection Agency. 2016 [cited 2019 Nov 28]. Available from:

https://www.epa.gov/ghgemissions/understanding-global-warming-potentials 
159. Allen MR, Shine KP, Fuglestvedt JS, Millar RJ, Cain M, Frame DJ, et al. A solution to the misrepresentations of $\mathrm{CO} 2$-equivalent emissions of short-lived climate pollutants under ambitious mitigation. Npj Clim Atmospheric Sci. 2018 Jun 4;1(1):1-8.

160. Tilman D, Cassman KG, Matson PA, Naylor R, Polasky S. Agricultural sustainability and intensive production practices. Nature. 2002 Aug;418(6898):671-7.

161. Sheldrick W, Keith Syers J, Lingard J. Contribution of livestock excreta to nutrient balances. Nutr Cycl Agroecosystems. 2003 Jun 1;66(2):119-31.

162. Goulding K, Jarvis S, Whitmore A. Optimizing nutrient management for farm systems. Philos Trans R Soc B Biol Sci. 2008 Feb 12;363(1491):667-80.

163. Rufino MC, Rowe EC, Delve RJ, Giller KE. Nitrogen cycling efficiencies through resource-poor African crop-livestock systems. Agric Ecosyst Environ. 2006 Mar 1;112(4):26182.

164. Fuhlendorf SD, Engle DM. Restoring Heterogeneity on Rangelands: Ecosystem Management Based on Evolutionary Grazing Patterns: We propose a paradigm that enhances heterogeneity instead of homogeneity to promote biological diversity and wildlife habitat on rangelands grazed by livestock. BioScience. 2001 Aug 1;51(8):625-32.

165. Herrero M, Havlík P, Valin H, Notenbaert A, Rufino MC, Thornton PK, et al. Biomass use, production, feed efficiencies, and greenhouse gas emissions from global livestock systems. Proc Natl Acad Sci. 2013 Dec 24;110(52):20888.

166. Laca E, Demment W. Livestock Production Systems. In: Management of Agricultural, Forestry, Fisheries and Rural Enterprise - Volume I. Oxford, UK: EOLSS Publishers/UNESCO; 2009.

167. Steinfeld $\mathrm{H}$, Wassenaar $\mathrm{T}$, Jutzi S. Livestock production systems in developing countries: status, drivers, trends. Rev Sci Tech Int Off Epizoot. 2006 Aug;25(2):505-16.

168. FAO. Land use Indicators - Land Under Perm. Meadows and Pastures - Share in Land Area (2017 data) [Internet]. FAOStat. 2020 [cited 2020 May 15]. Available from: http://www.fao.org/faostat/en/\#data/EL

169. Troell M, Jonell M, Crona B. The role of seafood in sustainable and healthy diets: The EAT-Lancet Commission report through a blue lens. Stockholm: Stockholm Resilience Centre; 2019.

170. Adesogan AT, Havelaar AH, McKune SL, Eilittä M, Dahl GE. Animal source foods: Sustainability problem or malnutrition and sustainability solution? Perspective matters. Glob Food Secur. 2019 Oct 14;100325.

171. FAO. Food wastage footprint: impacts on natural resources. Rome: Food and Agriculture Organization of the United Nations; 2013.

172. FAO. FAO's work on climate change: Fisheries \& aquaculture. Rome: Food and Agriculture Organization of the United Nations; 2019. 
173. Pelletier N, Tyedmers P, Sonesson U, Scholz A, Ziegler F, Flysjo A, et al. Not All Salmon Are Created Equal: Life Cycle Assessment (LCA) of Global Salmon Farming Systems. Environ Sci Technol. 2009 Dec 1;43(23):8730-6.

174. FAO. The State of World Fisheries and Aquaculture 2016 - Contributing to food security and nutrition for all. Rome: Food and Agriculture Organization of the United Nations; 2016.

175. McClelland SC, Arndt C, Gordon DR, Thoma G. Type and number of environmental impact categories used in livestock life cycle assessment: A systematic review. Livest Sci. 2018 Mar 1;209:39-45.

176. Clune S, Crossin E, Verghese K. Systematic review of greenhouse gas emissions for different fresh food categories. Eco-Effic Agric Food Syst Sel Pap Addressing Glob Chall Food Syst Those Present Conf "LCA Feed Planet Energy Life" 6-8 Oct 2015 Stresa Milan Expo Italy. 2017 Jan 1;140:766-83.

177. Hicks CC, Cohen PJ, Graham NAJ, Nash KL, Allison EH, D'Lima C, et al. Harnessing global fisheries to tackle micronutrient deficiencies. Nature. 2019 Oct;574(7776):95-8.

178. Gerber P, Vellinga T, Opio C, Steinfeld H. Productivity gains and greenhouse gas emissions intensity in dairy systems. Spec Issue Assess Sustain Dev Anim Prod Syst. 2011 Jul $1 ; 139(1): 100-8$.

179. Enahoro D, Mason-D'Croz D, Mul M, Rich KM, Robinson TP, Thornton P, et al. Supporting sustainable expansion of livestock production in South Asia and Sub-Saharan Africa: Scenario analysis of investment options. Glob Food Secur. 2019 Mar 1;20:114-21.

180. FAO. Greenhouse gas emissions from the dairy sector: A life cycle assessment. Rome: Food and Agriculture Organization of the United Nations; 2010.

181. Mottet A, Henderson B, Opio C, Falcucci A, Tempio G, Silvestri S, et al. Climate change mitigation and productivity gains in livestock supply chains: insights from regional case studies. Reg Environ Change. 2017 Jan;17(1):129-41.

182. Thornton PK, Herrero M. Potential for reduced methane and carbon dioxide emissions from livestock and pasture management in the tropics. Proc Natl Acad Sci. 2010 Nov 16;107(46):19667.

183. Gerber PJ, Hristov AN, Henderson B, Makkar H, Oh J, Lee C, et al. Technical options for the mitigation of direct methane and nitrous oxide emissions from livestock: a review. animal. 2013 Jun;7(s2):220-34.

184. Monteny G-J, Bannink A, Chadwick D. Greenhouse gas abatement strategies for animal husbandry. Agric Ecosyst Environ. 2006 Feb 1;112(2):163-70.

185. Rockström J, Lannerstad M, Falkenmark M. Assessing the water challenge of a new green revolution in developing countries. Proc Natl Acad Sci. 2007 Apr 10;104(15):6253-60.

186. Oenema O, Oudendag D, Velthof GL. Nutrient losses from manure management in the European Union. Recycl Livest Manure Whole-Farm Perspect. 2007 Dec 1;112(3):261-72. 
187. Cuéllar AD, Webber ME. Cow power: the energy and emissions benefits of converting manure to biogas. Environ Res Lett. 2008 Jul;3(3):034002.

188. zu Ermgassen EKHJ, Phalan B, Green RE, Balmford A. Reducing the land use of EU pork production: where there's swill, there's a way. Food Policy. 2016 Jan 1;58:35-48.

189. Jayathilakan K, Sultana K, Radhakrishna K, Bawa AS. Utilization of byproducts and waste materials from meat, poultry and fish processing industries: a review. J Food Sci Technol. 2012 Jun;49(3):278-93.

190. Bogard JR, Farmery AK, Little DC, Fulton EA, Cook M. Will fish be part of future healthy and sustainable diets? Lancet Planet Health. 2019 Apr 1;3(4):e159-60.

191. Conant RT, Paustian K. Potential soil carbon sequestration in overgrazed grassland ecosystems. Glob Biogeochem Cycles. 2002 Dec 1;16(4):90-1.

192. Henderson BB, Gerber PJ, Hilinski TE, Falcucci A, Ojima DS, Salvatore M, et al. Greenhouse gas mitigation potential of the world's grazing lands: Modeling soil carbon and nitrogen fluxes of mitigation practices. Agric Ecosyst Environ. 2015 Sep;207:91-100.

193. Conant RT, Cerri CEP, Osborne BB, Paustian K. Grassland management impacts on soil carbon stocks: a new synthesis. Ecol Appl. 2017 Mar;27(2):662-8.

194. Briske DD, Ash AJ, Derner JD, Huntsinger L. Commentary: A critical assessment of the policy endorsement for holistic management. Agric Syst. 2014 Mar;125:50-3.

195. Weindl I, Lotze-Campen H, Popp A, Müller C, Havlík P, Herrero M, et al. Livestock in a changing climate: production system transitions as an adaptation strategy for agriculture. Environ Res Lett. 2015 Sep 1;10(9):094021.

196. Thornton PK, van de Steeg J, Notenbaert A, Herrero M. The impacts of climate change on livestock and livestock systems in developing countries: A review of what we know and what we need to know. Agric Syst. 2009 Jul 1;101(3):113-27.

197. Lynch SA, Mullen AM, O'Neill E, Drummond L, Álvarez C. Opportunities and perspectives for utilisation of co-products in the meat industry. Qual Integr Glob Consum 64th Int Congr Meat Sci Technol Melb Aust. 2018 Oct 1;144:62-73.

198. Mills DJ, Westlund L, Graaf G de, Kura Y, Willman R, Kelleher K. Under-reported and undervalued: small-scale fisheries in the developing world. In: Pomeroy RS, Andrew NL, editors. Small-scale fisheries management: frameworks and approaches for the developing world [Internet]. Wallingford: CABI; 2011 [cited 2019 Dec 2]. p. 1-15. Available from: http://www.cabi.org/cabebooks/ebook/20113041514

199. Pica C, Pica-Ciamarra U, Otte J. The livestock sector in the World Development Report 2008: re-assessing the policy priorities. Rome: Food and Agriculture Organization of the United Nations; Report No.: Pro-Poor Livestock Policy Initiative Research Report No. 0807.

200. Omamo SW, Diao X, Wood S, Chamberlin J, You L, Sam Benin, et al. Strategic priorities for agricultural development in Eastern and Central Africa [Internet]. Washington, 
DC: International Food Policy Research Institute (IFPRI); 2006 [cited 2019 Nov 29]. Available from: http://ebrary.ifpri.org/cdm/ref/collection/p15738coll2/id/125234

201. Kristjanson P, Krishna A, Radeny M, Nindo W. Pathways out of poverty in western Kenya and the role of livestock. Rome: Food and Agriculture Organization of the United Nations; 2004. Report No.: PPLPI Working Paper No. 14.

202. Njuki J, Waithanji E, Lyimo-Macha J, Kariuki J, Mburu S, editors. Women, Livestock Ownership and Markets: Bridging the Gender Gap in Eastern and Southern Africa. 1 edition. Abingdon, Oxon; New York: Ottawa: Routledge; 2013. 168 p.

203. Kristjanson P, Waters-Bayer A, Johnson N, Tipilda A, Njuki J, Baltenweck I. Livestock and Women's Livelihoods: A Review of the Recent Evidence. Nairobi: International Livestock Research Institute; Report No.: ILRI Discussion Paper No. 20.

204. World Bank. Minding the Stock: Bringing Public Policy to Bear on Livestock Sector Development. Washington, DC: World Bank; 2009.

205. Robinson TP, Wint GRW, Conchedda G, Van Boeckel TP, Ercoli V, Palamara E, et al. Mapping the Global Distribution of Livestock. Baylis M, editor. PLoS ONE. 2014 May 29;9(5):e96084.

206. Wong JT, de Bruyn J, Bagnol B, Grieve H, Li M, Pym R, et al. Small-scale poultry and food security in resource-poor settings: A review. Glob Food Secur. 2017 Dec 1;15:43-52.

207. Thornton PK, Herrero M. Integrated crop-livestock simulation models for scenario analysis and impact assessment. Agric Syst. 2001 Nov 1;70(2):581-602.

208. Ellis F, Freeman HA. Rural Livelihoods and Poverty Reduction Strategies in Four African Countries. J Dev Stud. 2004 Apr;40(4):1-30.

209. Lay S. Media Release: Government partners with fintech firms to enable use of livestock as collateral. Medium [Internet]. 2018 May 17 [cited 2019 Nov 26]; Available from: https://medium.com/sentinelchain/media-release-government-partners-with-fintech-firms-toenable-use-of-livestock-as-collateral-852852a7e000

210. United Nations. United Nations framework convention on climate change. New York: United Nations; 1992.

211. Shue H. Global Environment and International Inequality. Int Aff. 1999 Jul;75(3):53145.

212. Paavola J, Adger WN. Fair adaptation to climate change. Ecol Econ. 2006 Apr;56(4):594-609.

213. Kates RW. Cautionary Tales: Adaptation and the Global Poor. Clim Change. 2000 Apr $1 ; 45(1): 5-17$.

214. IFPRI. Global Nutrition Report 2016: From Promise to Impact: Ending Malnutrition by 2030. Washington, DC: International Food Policy Research Institute (IFPRI); 2016.

215. World Bank. Employment in agriculture (\% of total employment) (modeled ILO estimate) [Internet]. World Bank Dataverse. 2019 [cited 2019 Jun 12]. Available from: 
https://data.worldbank.org/indicator/SL.AGR.EMPL.ZS?end=2019\&most_recent_value_desc= true\&start=1991\&view=chart

216. Frumhoff PC, Heede R, Oreskes $N$. The climate responsibilities of industrial carbon producers. Clim Change. 2015 Sep;132(2):157-71.

217. Neumayer E. In defence of historical accountability for greenhouse gas emissions. Ecol Econ. 2000 May 1;33(2):185-92.

218. Thomas DSG, Twyman C. Equity and justice in climate change adaptation amongst natural-resource-dependent societies. Glob Environ Change. 2005 Jul;15(2):115-24.

219. Hubacek K, Baiocchi G, Feng K, Muñoz Castillo R, Sun L, Xue J. Global carbon inequality. Energy Ecol Environ. 2017 Dec;2(6):361-9.

220. Pretis F, Schwarz M, Tang K, Haustein K, Allen MR. Uncertain impacts on economic growth when stabilizing global temperatures at $1.5^{\circ} \mathrm{C}$ or $2^{\circ} \mathrm{C}$ warming. Philos Trans $\mathrm{R}$ Soc Math Phys Eng Sci. 2018 May 13;376(2119):20160460.

221. Caro D, Davis SJ, Bastianoni S, Caldeira K. Global and regional trends in greenhouse gas emissions from livestock. Clim Change. 2014 Sep 1;126(1):203-16.

222. FAO, WHO. Sustainable healthy diets - Guiding principles. Rome: Food and Agriculture Organization of the United Nations; 2019.

223. World Commission on Environment and Development, editor. Our common future. Oxford; New York: Oxford University Press; 1987. 383 p. (Oxford paperbacks).

224. Kim BF, Santo RE, Scatterday AP, Fry JP, Synk CM, Cebron SR, et al. Country-specific dietary shifts to mitigate climate and water crises. Glob Environ Change. 2019 Aug 7;101926.

225. Harris F, Moss C, Joy EJM, Quinn R, Scheelbeek PFD, Dangour AD, et al. The Water Footprint of Diets: A Global Systematic Review and Meta-analysis. Adv Nutr. 2019 Sep 6;nmz091.

226. Poore J, Nemecek T. Reducing food's environmental impacts through producers and consumers. Science. 2018 Jun 1;360(6392):987.

227. Willett W, Rockström J, Loken B, Springmann M, Lang T, Vermeulen S, et al. Food in the Anthropocene: the EAT-Lancet Commission on healthy diets from sustainable food systems. The Lancet. 2019 Feb 2;393(10170):447-92.

228. Frehner A, Muller A, Schader C, De Boer IJM, Van Zanten HHE. Methodological choices drive differences in environmentally-friendly dietary solutions. Glob Food Secur. 2020 Mar 1;24:100333.

229. Aleksandrowicz L, Green R, Joy EJM, Smith P, Haines A. The Impacts of Dietary Change on Greenhouse Gas Emissions, Land Use, Water Use, and Health: A Systematic Review. PLOS ONE. 2016 Nov 3;11(11):e0165797.

230. Fresán U, Sabaté J. Vegetarian Diets: Planetary Health and Its Alignment with Human Health. Adv Nutr. 2019 Nov 1;10(Supplement_4):S380-8. 
231. Hallström E, Carlsson-Kanyama A, Börjesson P. Environmental impact of dietary change: a systematic review. J Clean Prod. 2015 Mar 15;91:1-11.

232. Springmann M, Godfray HCJ, Rayner M, Scarborough P. Analysis and valuation of the health and climate change cobenefits of dietary change. Proc Natl Acad Sci. 2016 Apr $12 ; 113(15): 4146$.

233. Orlich MJ, Chiu THT, Dhillon PK, Key TJ, Fraser GE, Shridhar K, et al. Vegetarian Epidemiology: Review and Discussion of Findings from Geographically Diverse Cohorts. Adv Nutr. 2019 Nov 1;10(Supplement_4):S284-95.

234. Satija A, Bhupathiraju SN, Rimm EB, Spiegelman D, Chiuve SE, Borgi L, et al. PlantBased Dietary Patterns and Incidence of Type 2 Diabetes in US Men and Women: Results from Three Prospective Cohort Studies. PLOS Med. 2016 Jun 14;13(6):e1002039.

235. Satija A, Bhupathiraju SN, Spiegelman D, Chiuve SE, Manson JE, Willett W, et al. Healthful and Unhealthful Plant-Based Diets and the Risk of Coronary Heart Disease in U.S. Adults. J Am Coll Cardiol. 2017 Jul;70(4):411-22.

236. Sacks FM, Moore TJ, Appel LJ, Obarzanek E, Cutler JA, Vollmer WM, et al. A dietary approach to prevent hypertension: A review of the dietary approaches to stop hypertension (DASH) study. Clin Cardiol. 2009;22(S3):6-10.

237. Kuipers RS, Luxwolda MF, Dijck-Brouwer DAJ, Eaton SB, Crawford MA, Cordain L, et al. Estimated macronutrient and fatty acid intakes from an East African Paleolithic diet. $\mathrm{Br} \mathrm{J}$ Nutr. 2010 Dec;104(11):1666-87.

238. Cordain L, Eaton SB, Sebastian A, Mann N, Lindeberg S, Watkins BA, et al. Origins and evolution of the Western diet: health implications for the 21st century. Am J Clin Nutr. 2005 Feb 1;81(2):341-54.

239. Payne CL, Scarborough P, Cobiac L. Do low-carbon-emission diets lead to higher nutritional quality and positive health outcomes? A systematic review of the literature. Public Health Nutr. 2016 Oct;19(14):2654-61.

240. Chen C, Chaudhary A, Mathys A. Dietary Change Scenarios and Implications for Environmental, Nutrition, Human Health and Economic Dimensions of Food Sustainability. Nutrients. 2019 Apr 16;11(4):856.

241. Hu FB, Otis BO, McCarthy G. Can Plant-Based Meat Alternatives Be Part of a Healthy and Sustainable Diet? JAMA. 2019 Oct 22;322(16):1547.

242. Ridoutt BG, Hendrie GA, Noakes M. Dietary Strategies to Reduce Environmental Impact: A Critical Review of the Evidence Base. Adv Nutr Int Rev J. 2017 Nov;8(6):933-46. 